\title{
Landscape evolution and geodynamic controls in the Gulf of Cadiz (Huelva coast, SW Spain) during the Late Quaternary
}

\author{
Cari Zazo ${ }^{\mathrm{a}, *}$, Norbert Mercier ${ }^{\mathrm{b}}$, Pablo G. Silva ${ }^{\mathrm{c}}$, Cristino J. Dabrio ${ }^{\mathrm{d}}$, José Luis Goy ${ }^{\mathrm{c}}$, \\ Elvira Roquero ${ }^{\mathrm{e}}$, Vicente Soler ${ }^{\mathrm{f}}$, Francisco Borja ${ }^{\mathrm{g}}$, Javier Lario ${ }^{\mathrm{h}}$, \\ Dolores Polo ${ }^{\mathrm{d}}$, Luis de Luque ${ }^{\mathrm{a}}$ \\ ${ }^{a}$ Departamento de Geología, Museo Nacional de Ciencias Naturales-CSIC, 28006 Madrid, Spain \\ ${ }^{\mathrm{b}}$ Laboratoire des Sciences du Climat et de l'Environnement, CEA-CNRS, Av. de la Terrasse, 91198 Gif-Sur-Yvette Cedex, France \\ ${ }^{\mathrm{c}}$ Departamento de Geología, Facultad de Ciencias, Universidad, 37008 Salamanca, Spain \\ ${ }^{\mathrm{d}}$ Departamento de Estratigrafia-UCM and Instituto de Geología Económica-CSIC, Universidad Complutense, 28040 Madrid, Spain \\ e Departamento de Edafología, ETS I. Agrónomos, Universidad Politécnica, 28040 Madrid, Spain \\ ${ }_{\mathrm{f}}^{\mathrm{E}}$ stación Volcanológica de Canarias, Instituto de Productos Naturales-CSIC). Avenida Astrofísico Francisco Sánchez, \\ 3. 38206-La Laguna, Tenerife, Spain \\ ${ }^{\mathrm{g}}$ Área de Geografia Física, Facultad de Humanidades, Universidad de Huelva, 21007 Huelva, Spain \\ ${ }^{\mathrm{h}}$ Departamento de Ingeniería Geológica y Minera, Facultad de Ciencias del Medio Ambiente, \\ Universidad de Castilla La Mancha, Toledo, Spain
}

Received 24 March 2004; received in revised form 22 November 2004; accepted 24 November 2004

Available online 21 January 2005

\begin{abstract}
The coastal evolution of the El Abalario area (Huelva, southern Spain) during the Late Pleistocene and Holocene is reinterpreted after a refinement of the available geochronology by means of optically stimulated luminescence (OSL) dating. New data come from the analysis of soft sediment deformation, palaeosols, geomorphological mapping, and published seismic surveys on the onshore and offshore Gulf of Cadiz.

The present structure of El Abalario dome resulted from the complex interaction of littoral-catchment processes and sealevel changes upon an emergent coastal plain, conditioned by the upwarping of the underlying Pliocene-Pleistocene prograding deltaic sequence. Upwarping is probably related to escape of over-pressurized fluids, accompanied by dewatering, prior to (?) and during OIS (Oxygen Isotopic Stage) 5. Continued upwarping produced the large NW-SE gravitational fault of Torre del Loro (TLF) in the southwestern flank of the dome, roughly parallel to the present coastline during OIS 5-OIS 4. The resulting escarpment favoured the accumulation of aeolian sand dunes (units U1, U2, and U3) from OIS 5 to early OIS 1. Unit U1 (OIS 5) ends upwards in a supersurface with a thick weathering profile that suggests moist and temperate climatic conditions. Unit U2 accumulated mainly during OIS 4 and OIS 3 with prevailing W/E winds. The supersurface between U2
\end{abstract}


and U3 records a part of OIS 2, with relative low sea level. Sedimentation of unit U3 took place during the Last Deglaciation (radiocarbon and OSL ages) with prevailing W/SW winds, under a temperate moist climate, that became more arid towards the top (Holocene). A major supersurface with an iron crust-like layer (SsFe) developed during the Holocene Climatic Optimum (OIS 1) under wetter and more temperate conditions than before, fossilizing the TLF. The supersurface is covered by younger aeolian dunes (U4, U5, U6, and U7) transported by W-SW winds since the Late Neolithic-Chalcolithic cultural period $(\sim 5.0 \mathrm{ky}$ cal BP).

Keywords: Pleistocene-Holocene sediments; Optical ages; Palaeosol; Soft-sediment deformation; Gravity fault; Coastal changes

\section{Introduction}

The Abalario area (in the coastal area of the Gulf of Cadiz in southern Spain, southwestern Iberian Peninsula) is a morphological dome elongated in a NWSE direction that separates the Neogene Guadalquivir basin from the Atlantic Ocean. The northeast limit of the dome is the La Rocina River. To the southwest, the Asperillo cliff that forms the present coastline dissects the dome. To the southeast, the dome subsidesplunging underneath active dune fields-and serves as an anchor point of the Holocene spit barrier of Doñana that encloses the marshlands ("marismas") of Guadalquivir (Fig. 1).

The internal structure of the dome is exposed along the Asperillo cliff that extends for $28 \mathrm{~km}$ between the resorts of Mazagón and Matalascañas with average elevations around $20 \mathrm{~m}$. The cliff is being carved into weakly cemented sandstones by moderate energy waves of a mesotidal coast (mean tidal range slightly above $2 \mathrm{~m}$ ) and undergoes active retreat. The climate is Mediterranean with an Atlantic influence (Font Tullot, 1983), having an average temperature $\sim 18{ }^{\circ} \mathrm{C}$, mean precipitation $\sim 600 \mathrm{~mm}$, and prevailing SW and subordinate $\mathrm{E}$ and $\mathrm{SE}$ winds.

Previous sedimentological interpretations of sandstones exposed in the cliff proposed Holocene aeolian (Caratini and Viguier, 1973) or PliocenePleistocene marine origins (Pastor et al., 1976). In contrast, Zazo et al. (1981) used sedimentary facies analysis to characterize fluvial, marine and aeolian deposits. Radiocarbon-dating of a clay layer rich in organic matter at the top of the fluvial unit yielded ages beyond the range of the method. Borja and Díaz del Olmo (1994, 1996) mapped the aeolian deposits and used radiocarbon to date some of the interbedded organic layers. Later, Dabrio et al. (1996) elaborated the first models of aeolian sedimentation for this area.

Neotectonic activity along this coast is revealed by normal faults such as the Torre del Loro fault (TLF after Goy et al., 1994) that exerted a main control on sedimentation during the Quaternary. Zazo et al. (1999a) used sedimentary facies analysis, palaeocurrent measurements, subsurface data from hydrological drillings (IGME, 1980, Salvany and Custodio, 1995), and some 30 radiocarbon measurements (AMS and conventional) to prove that the TLF separated two palaeogeographic domains (Fig. 2). The upthrown tectonic block contains fluvial, marine and aeolian deposits (in ascending stratigraphic order), whereas the downthrown block trapped aeolian sediments and laterally discontinuous sand layers rich in organic matter, in which three units (U1 to U3) were identified. Based on radiocarbon ages and regional geological data, Zazo et al. (1999a) assigned an Early-Middle Pleistocene age to the fluvial unit and Middle-Late Pleistocene to the littoral units. The aeolian deposits stacked in the downthrown block were considered to have accumulated during the last part of the Last Interglacial period (U1), Last Glacial (U2) and Last Deglaciation (U3). A surface enriched in iron oxide fossilized the fault trace sealing the two fault blocks (Fig. 2); it is covered by younger semi-mobile and mobile aeolian dunes (U4, U5 and U6) that accumulated mostly after the Middle Holocene growing to topographic elevations above $100 \mathrm{~m}$.

The aim of this work is to understand the history of catchment-coast linkage during the Late Quaternary in an emergent sandy coast in order to evaluate the driving mechanisms that acted on coastal evolution 


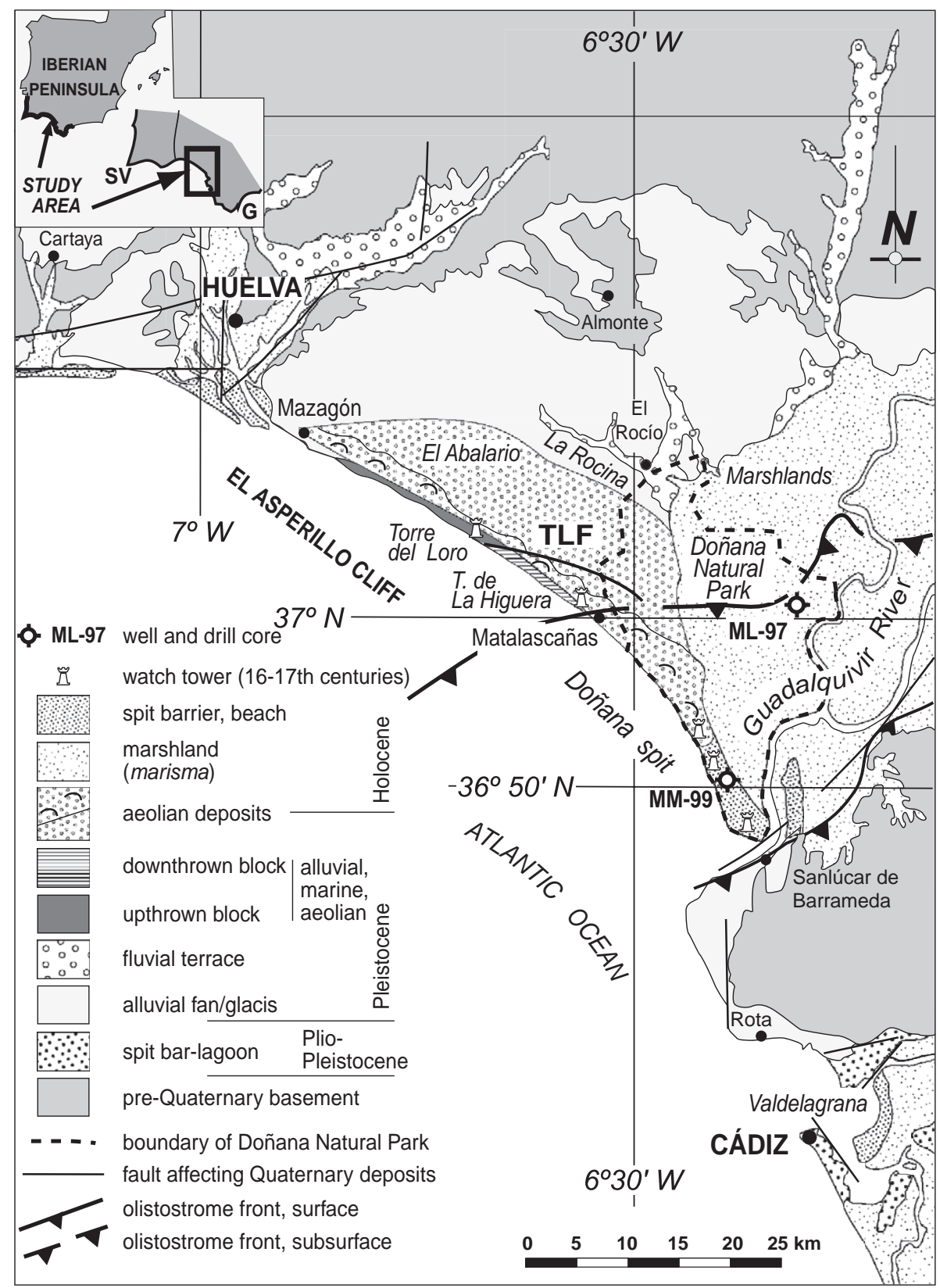

Fig. 1. Location map and geological sketch of the Abalario area. Key: ML-97 (Mari López borehole, Zazo et al., 1999b), G: Rock of Gibraltar, SV: Cape San Vicente.

(one of the main topics of the IGCP 495 Project: "Quaternary Land-Ocean Interactions"). New chronological data (OSL), together with analyses of the best developed paleosols and soft-sediment deformation features are used to explore the feedback relationships among sea-cliff generations, sea-level changes, sea-cliff degradation and the consequent succession of littoral landscapes over time. In addition, the combined study of geomorphological anomalies in the drainage pattern and the available 


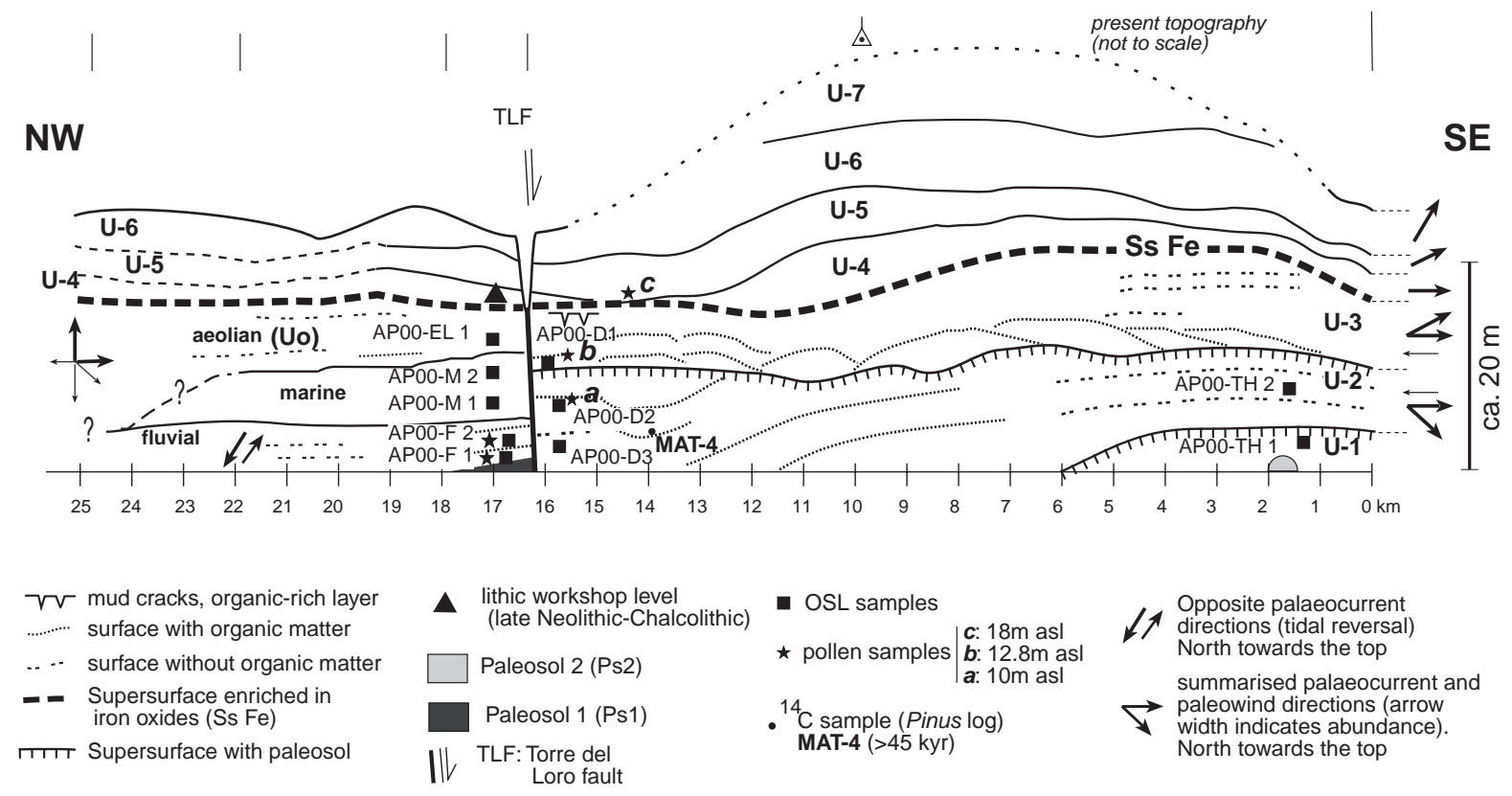

Fig. 2. Schematic profile showing the distribution of sedimentary units and palaeosols. Note the strong vertical exaggeration. Distances in km from Torre de la Higuera watchtower (modified from Zazo et al., 1999a).

onshore seismic lines allowed us to define the processes behind the upwarping in the former sandy coastal plain of the Gualdalquivir River.

\section{Methodology}

The elevation of the deposits is given relative to the mean annual average high tide (datum zero) with indication of above (asl) or below (bsl) mean high tide level. Given the difficulty of finding landmarks along the monotonous, almost straight, scarp of the Asperillo cliff, we used a portable GPS (Global Positioning System) device to obtain latitudinal and geographical coordinates. The starting line for distances used in figures and text is the ruined watchtower of Torre de la Higuera (Matalascañas), proceeding towards the northwest for $28 \mathrm{~km}$ (Figs. 1 and 2).

Mineralogy, micromorphology and geochemical analyses were carried out on samples from palaeosols Ps1, Ps2, and SsFe (Fig. 2). Mineralogy of grain size fractions $<2 \mathrm{~mm}$ and $<0.002 \mathrm{~mm}$ was analysed in a Philips PV 1170 X-ray diffractometer. Samples for micromorphology were prepared from undisturbed samples, and thin sections were studied with polarizing microscope according to Bullock et al. (1985) description. Colours of palaeosols are referred according to Munsell Color Chart (1990). Chemical analyses were carried out in a Perkin-Elmer 2380 atomic absorption spectrophotometer. Radiocarbon data: ${ }^{14} \mathrm{C}$ ages used in this paper correspond essentially to aeolian U3 and the upper part of U2 (see Zazo et al., 1999a).

Five samples were collected for Optically Stimulated Luminescence (OSL) in each block of the TLF profiles (Fig. 2). Sampling was achieved by hammering 20-cm-long aluminium pipes in the profiles, after scraping the surface to avoid contamination by recently bleached grains.

All samples were treated in the laboratory under subdued red light in order to minimize artificial bleaching. The 100-125 $\mu \mathrm{m}$ grain size fraction was selected by dry sieving and treated with hydrochloric acid and hydrogen peroxide to remove carbonates and organic matter, respectively. High-density solutions were used to concentrate the quartz fraction, which was then treated with $40 \%$ hydrofluoric acid for 40 
min and rinsed with hydrochloric acid. Finally, the residual grain fraction was re-sieved with a $100 \mu \mathrm{m}$ mesh to eliminate grains which size was reduced during the chemical treatment (especially feldspars). More details on the method are given in Section 4.

\section{Sedimentary record of the Abalario in the Asperillo cliff}

Since a detailed sedimentological study of the sedimentary units cropping out along this sea-cliff is available in Zazo et al. (1999a), we offer a summary of the data in Table 1. New observations reported here refer to the uppermost surface of the Asperillo cliffs, and also to the deposits uncovered recently at the toe-cliff following beach evolution or cliff failures.

The studied sedimentary succession records the Pleistocene-Holocene evolution of the littoral sector of the Guadalquivir Basin at the Gulf of Cadiz. The entire Pliocene-Pleistocene filling of the Guadalquivir basin consists of a stack of wedge-shaped sedimentary lithosomes prograding towards the southwest observed in seismic profiles both onshore (ITGE, 1990; Ledesma, 2001) and offshore (Somoza et al., 1997; Rodero et al., 1999; Hernández Molina et al., 2000, 2002). It is currently assumed that these siliciclastic wedges accumulated in deltaic to coastal plain settings with their ancient sedimentary fronts presently located offshore in the Atlantic Ocean (Riaza and Martínez del Olmo, 1996; Hernández Molina et al., 2000, 2002).

Onshore, these siliciclastic wedges are represented by several sedimentary formations, such as the Pliocene-Pleistocene deltaic sedimentary unit of described by Salvany and Custodio (1995), and the Arenas de Bonares Formation studied by Mayoral and Pendón (1986-1987). Both sedimentary formations have been characterised by field and borehole data, displaying diagnostic features, such as a high content of weathered iron deposits, fersialitic soils, and ferruginous concretions. In particular in the zone of the El Abalario Dome, these sandy materials have been found in borehole records at depths close to the current sea-level (Salvany and Custodio, 1995). Therefore, we assign the sandy deposits exposed at the base of El Asperillo cliff, beneath the El Abalario
Dome, to one of the Pleistocene siliciclastic wedges deposited in a coastal plain.

\subsection{Units in the upthrown fault block (Figs. 2 and $3 A$, $B, C$, and Table 1)}

\subsubsection{Palaeosol Ps1}

Near the TLF (Figs. 2 and 3A), sandy sediments at the toe of the cliff include a yellowish-brown (10YR $5 / 8 \mathrm{~m}$ in wet material) weathering profile, 1$1.5 \mathrm{~m}$ thick (Fig. 3C, D), with redoximorphic features shown as mottling with $20-30 \mathrm{~cm}$ wide, sharp-sided, light grey (10YR 7/1m) segregations. Segregations in the exposed upper $105 \mathrm{~cm}$ tend to be elongated in a vertical direction; towards the lower part they are more irregular and tend to be horizontal. Smaller reddish brown (5YR 5/8m) or yellowish red $(2.5$ YR $5 / 8 \mathrm{~m})$ mottling occurs at the lowermost (exposed) $50 \mathrm{~cm}$. In other places the reddish mottling concentrates in millimetric thick laminae that overlie a very undulated, indurate ironoxide crust.

The mineralogy of the original and discoloured zones is very similar, with quartz content about 68 $74 \%$, microcline $2-3 \%$, micas $7-12 \%$, and kaolinite $13-14 \%$. The main differences are that the original yellowish brown matrix contains goethite $(1 \%)$ and a higher amount $(2 \%)$ of hematite, whilst the discoloured mottles contain ilmenite $(1 \%)$ and magnetite $(2 \%)$. Chemical analyses confirm these differences: $\mathrm{Fe}_{2} \mathrm{O}_{3}$ amounts to $4.69 \mathrm{ppm}$ in the original matrix and $0.93 \mathrm{ppm}$ in the discoloured. The highly mobile $\mathrm{Mn}$ is absent because it has migrated downward through out the weathering profile.

Micromorphological study of low chroma mottles reveals a discoloured pale greyish-brown groundmass with depletion pedofeatures dominated by hypocoatings. In contrast, the groundmass of the reddish mottling and segregations is more variable, with discoloured brown, dark brown (sometimes isotropic), and reddish domains. Dominant pedofeatures record accumulation and depletion: accumulation of iron oxides is marked by intense impregnation of the groundmass; depletion hypocoatings occur associated with the abundant, interconnected planar voids.

Birefringent clay patches visible as dense, incomplete infillings or coatings indicate intense illuviation that took place before the mobilization and precip- 


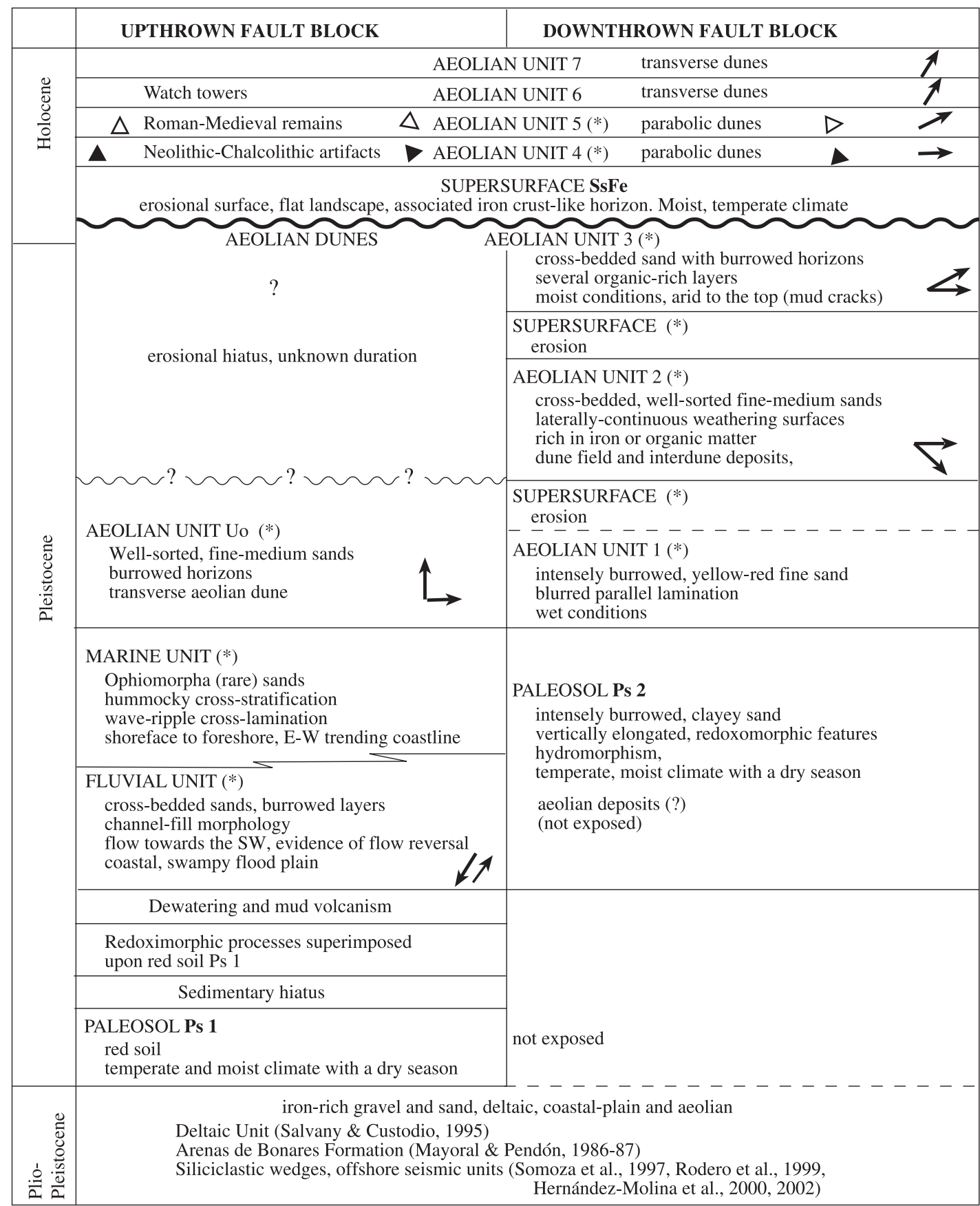

(*): Units described in Zazo et al. (1999a). 

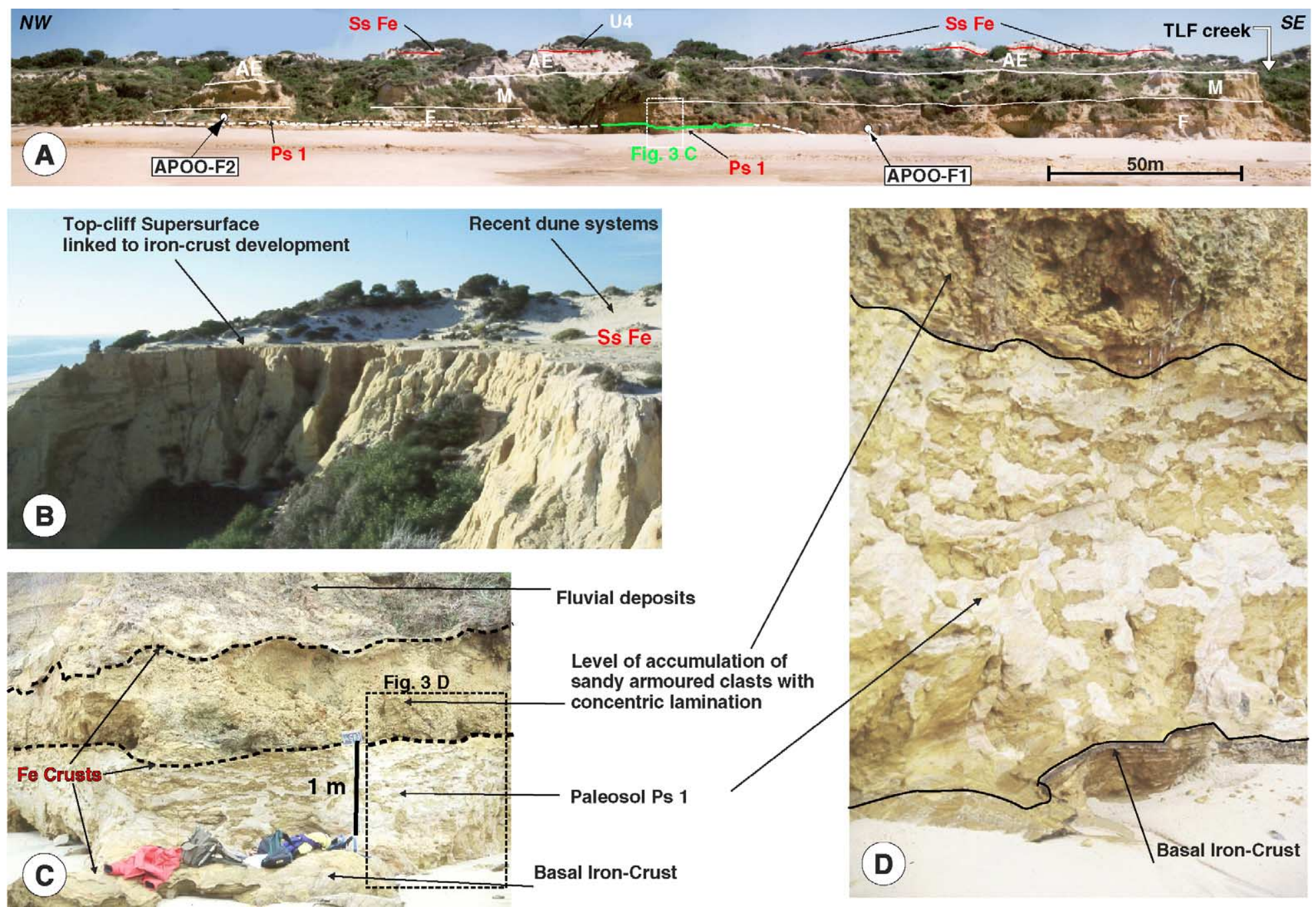

Fig. 3. Geological features in the upthrown Torre del Loro (TLF) fault block. A: Panoramic view (see Fig. 6 for location) with indication of OSL samples in white boxes. Key: Ps 1 : palaeosol, F: Fluvial deposits, M: Marine deposits, AE: Aeolian deposits, SsFe: Iron crust-like horizon. B: Supersurface with remains of the partly-eroded iron crust-like horizon (SsFe), near Parador Nacional (see Fig. 2). C: Palaeosol Ps 1 between the underlying iron crust and the overlaying iron crust and accumulation of armoured sand balls (see text for explanation). D: Detail of the large-grey mottling in the yellowish brown matrix of palaeosol Ps 1. Note the vertical trend in morphology, sharp limits and connections between mottles (exposed thickness ca. $1.2 \mathrm{~m}$ ). 
itation of iron oxides. Later iron migration is shown by weak (in the reddish brown groundmass) and intense (in the dark brown patches) impregnations with diffuse borders that locally obliterate or mask the aforementioned clay pedofeatures.

Weathering was a complex process. Pedogenic processes of eluviation and redistribution were later masked by mobilization of iron and manganese. These processes must be related to a well-developed plant cover living on mature soils, as revealed by micromorphological studies. Ample fluctuations of the phreatic water table caused successive periods of saturation (reduction) and desaturation (oxidation), which produced redoximorphic features. However, we cannot rule out microbial decay around plant roots under limited $\mathrm{O}_{2}$ supply (Fey, 1983; Barrón and Torrent, 1987) that amplified the already-anaerobic conditions. We assume that the discoloured zones (low chroma mottles) are related to root activity, and those with vertical trend may correspond to the exploratory zone of roots.

Other parts of the profile are almost completely discoloured, with only small isolated patches of the 'original' yellowish brown matrix. This indicates long-lasting or permanent saturation by reducing waters, interpreted as a stable phreatic water table.

The sequence of Ps1 pedogenetic processes affecting the top of siliciclastic wedges (Deltaic unit of Salvany and Custodio, 1995) can be summarized as a two-step process (Table 1). First, development of a red soil under Mediterranean climate conditions during a sedimentary hiatus. Later, fluctuations of the water table under moister conditions favoured a well-developed vegetal cover, and triggered strong redoximorphic processes superimposed to the red soil.

Adjacent to the TLF iron-crusts develop at the base of the soil-profile (Fig. 3B), whilst the upper soil limit is buried by mound-shaped layers consisting on richiron sandy armoured balls (Fig. 3C).

\subsection{Units in the downthrown fault block (Figs. 2 and 4 A through D, Table 1)}

The oldest unit exposed is palaeosol Ps2 that crops out near Torre de la Higuera (Matalascañas). It is followed upwards by several aeolian units. At least two types of bounding surfaces have been distin- guished in the three lower units $(1,2,3)$. Interdune surfaces separate sets of large-scale cross-bedding during essentially constructional phases, whereas larger, laterally more continuous, supersurfaces (cf. Kocurek and Havholm, 1993; Havholm and Kocurek, 1994) are associated with erosion that truncates a previous surface with plant colonization and pedogenesis during stabilization phases.

\subsubsection{Palaeosol Ps2}

Near Torre de la Higuera (Figs. 2 and 4A) the base of the cliff is occupied by clayey sands, somewhat plastic and adherent, with segregations of 10 to $20 \mathrm{~cm}$ in diameter. The dominantly vertical elongation suggests a genetic relation with roots. Segregations in the zones of root activity have a concentric structure with a pale-yellow $(2.5 \mathrm{Y} / 4 \mathrm{~m})$ nucleus that changes at the periphery to intense brown (7.5YR 5/ $8 \mathrm{~m}$ ) and, finally, to the preserved remains of the original red (2.5 YR4/6m) matrix of the soil (Fig. 4D). Mineralogy of the brown and reddish zones is very similar: quartz $(70-71 \%)$, microcline $(3 \%)$, ilmenite $(1 \%)$, hematite $(1 \%)$, goethite $(1 \%)$, micas $(6 \%)$, and kaolinite (18-19\%).

Widespread occurrence of typical and crescent coatings of well-oriented illuvial clay (ferriargillans) and dense complete and incomplete fillings reveal intense clay illuviation that eventually generated an argillic horizon of unknown thickness owing to poor exposure. Redoximorphic features observed in the field are confirmed in micro-morphological study by domains of discoloured matrix where the clay coatings exhibit a chromatic gradation from reddish brown, to orange brown, to the very light yellowishbrown of the nucleus of segregations. The origin of mottling and segregations is related to hydromorphic processes that took place after pedogenic clay translocation, mostly in reducing microenvironments around roots that favoured dissolution and mobilization of $\mathrm{Fe}^{2+}$. The sequence of pedogenic processes is similar to the described for Ps1 but the redoximorphic processes appear less developed.

\subsection{The post-U3 supersurface ( $\mathrm{SsFe}$ ) exposed in the Asperillo cliff}

After deposition of U3, an erosional phase partly levelled the topographic irregularities producing a 

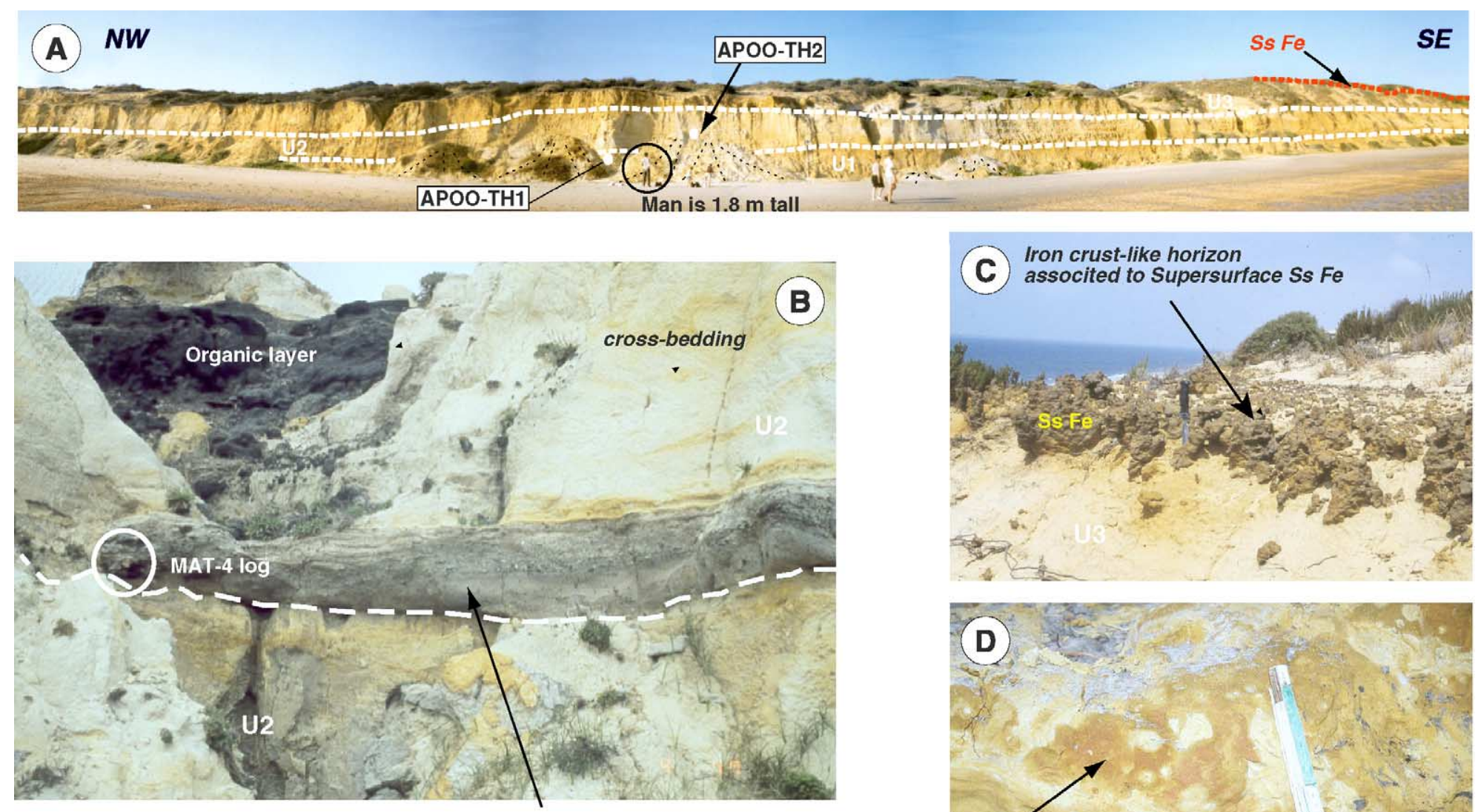

Thalweg of paleovalley inside $U 2$

Basal mottled iron-rich paleosol (Ps 2) underneath U1
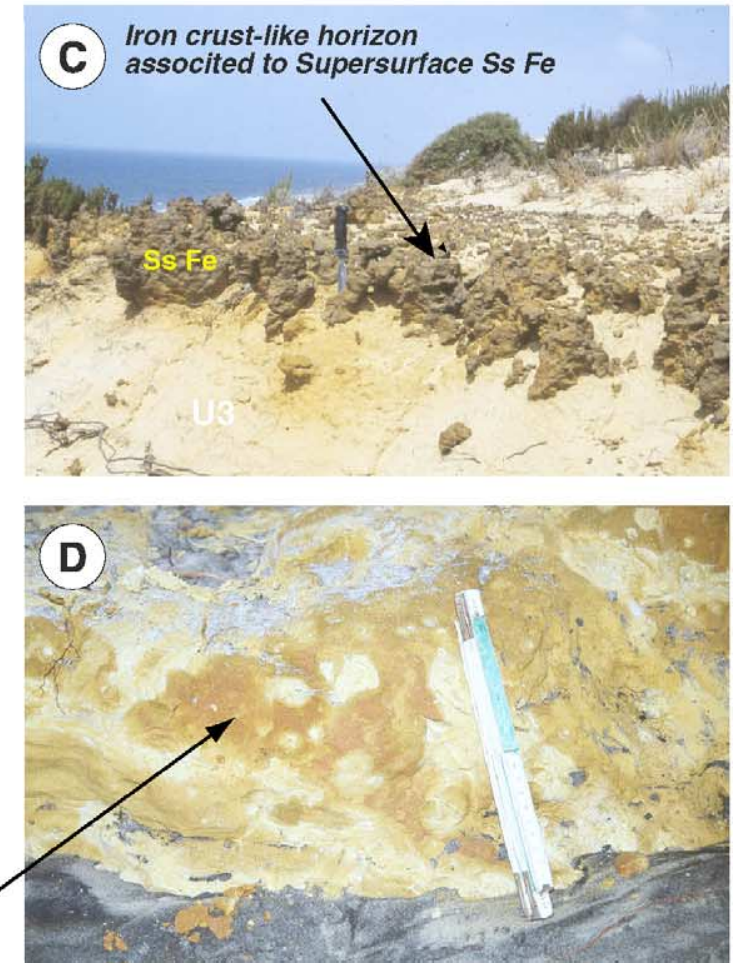

Fig. 4. Geological features in the downthrown Torre del Loro (TLF) fault block. A: Panoramic view (see Fig. 6 for location) with indication of OSL samples in white boxes. Key: U1, U2 and U3, aeolian units 1, 2, 3, respectively. B: Detail of a cinder-rich sandy layer with charred Pinus $\log$ (sample MAT-4) at the bottom of an erosional paleovalley inside aeolian U2 (km 14, see Fig. 2), followed upwards by aeolian sands and younger organic-rich layers. C: Supersurface with iron crust-like horizon (SsFe) exposed at km 1 (see Fig. 2). D: Detai of palaeosol Ps 2 (folded ruler: $20 \mathrm{~cm}$ long) showing concentric structure and transitions from a pale-yellow nucleus to intense brown and externally red original matrix, related to root activity. 
largely-flat landscape that eventually evolved into a major supersurface recognizable along the whole cliff (Figs. 2, 3A, D, and 4A) with an associated iron crustlike horizon (Fig. 4C, Table 1).

Mineralogical analyses reveal the dominance of quartz (90-75\%) and the occurrence of goethite $(10-25 \%)$ as the only iron oxide, a feature interpreted as indicative of cool temperate climates (Schwertmann and Taylor, 1989). As goethite formation is favoured when soil moisture increases and also by high contents in organic matter, this layer suggests relatively continuous rainfall able to support herbaceous substrata with abundant shallow roots that supplied organic matter to the soil profile.

\subsection{Micro and macro wood fragments}

Although there are many discontinuous layers rich in organic matter interbedded in the aeolian deposits and topping the fluvial unit in some places (Fig. 2), pollen analyses in a stratigraphic section are restricted so far to a few layers near the TLF (Zazo et al., 1999a). Two sets of samples can be separated depending on local hydrological conditions. Samples collected at the top of the fluvial unit contain aquatic pollen, especially Myriophylum, a taxon linked to fresh water. In contrast, samples collected in organic layers of aeolian units $10 \mathrm{~m}$ asl (U2, layer $\boldsymbol{a}$ in Fig. 2) and $12.8 \mathrm{~m}$ asl (U3, layer $\boldsymbol{b}$ in Fig. 2) lack aquatic pollen and contain mainly shrubs associated with Pinus, and scattered occurrences of thermophilous trees (Alnus, Betula, Carpinus, Quercus, etc.). The assemblages collected from the upper part of U2 and the lower part of U3 are similar. The abundance of Erica and Cistus in U5 (layer $c$ in Fig. 2) records the degradation of the natural vegetation during the late Holocene.

Macroscopic wood fragments (vegetal megaremains) are relatively frequent in the aeolian deposits. Some of them, collected near Torre del Loro, are currently under study by another research team. Analyses of anatomical features of fossil wood from the lower part of the cliff in U2 (km 15-16 at elevation 0 to $1 \mathrm{~m}$ asl) reveal the existence of a group of microthermic species (among them Pinus nigra). Nowadays these taxa are found in areas far away from the shore, mainly in mountains, uplands and moist areas (hygrophilous surroundings) of the Iberian Peninsula (Postigo and Morla, pers. com.).

Taking into account that the present-day bioclimatic stage in southern Iberia including littoral areas is thermo-Mediterranean (Rivas Martínez, 1987), it is necessary to invoke at least a sharp change in vegetation during the deposition of $\mathrm{U} 2$.

\section{Luminescence dating}

Because of the abundance of quartz grains in the aeolian, fluvial and marine deposits, the Optically Stimulated Luminescence (OSL) method seemed well suited for radiometric dating. This method relies on the ability of certain minerals, such as quartz, to accumulate and store over long periods of time, the energy received from ionizing radiation. When grains are exposed to sunlight during transport and deposition, the previously accumulated radiation dose is reduced to zero (if the bleaching time is sufficient) and the grains acquire dose after their burial, at a rate dependent on the environmental radioactivity. The time elapsed since the grains were buried can be calculated by determining the total accumulated dose (or Equivalent Dose, ED) and the dose-rate to which they were subjected (Aitken, 1998).

\subsection{Radiometric measurements}

Gamma and cosmic dose-rates were measured in the field by inserting a portable spectrometer equipped with a 1.5 in. $\mathrm{NaI}$ detector in the holes made during sampling. Radioisotopic contents (U, Th, K) of the sediment samples were determined in the laboratory by high-resolution gamma spectrometry. Beta dose-rates were then deduced from these contents (Table 2) and from conversion factors given by Adamiec and Aitken (1998). For each sample, the water content was measured in the laboratory and used for dose-rate calculations. As all quartz grains had been etched by the hydrofluoric acid treatment, the residual alpha dose-rate was found not to exceed a few percent of the total dose-rate. The spectrometric measurements also allowed us to check that the $U$ and Th-series were at secular equilibrium, suggesting that dose-rates did 


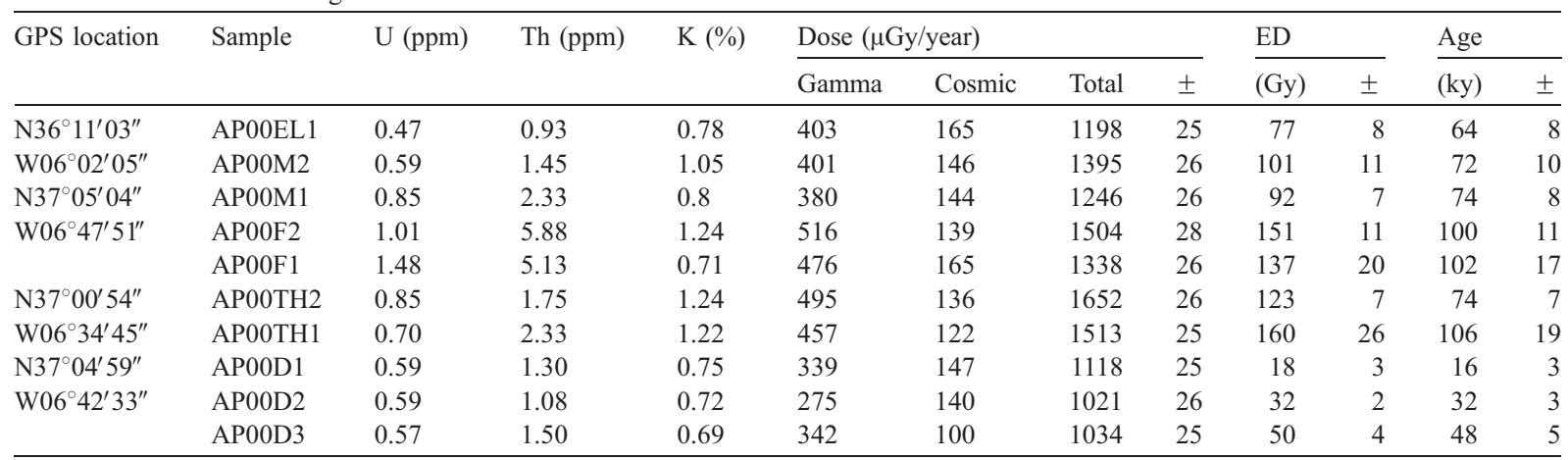

Errors are given in one sigma level.

Each disc was pre-heated at $220{ }^{\circ} \mathrm{C}$ for $10 \mathrm{~s}$ and optically stimulated at $125{ }^{\circ} \mathrm{C}$ to prevent re-trapping of charges in the $110^{\circ} \mathrm{C}$ TL trap (Wintle and Murray, 1997). A test dose of about $50 \%$ of the expected ED was used to monitor sensitivity changes.

not change significantly during the burial of the sediments.

\subsection{Luminescence measurements and EDs calculations}

Luminescence measurements were performed using either an automated TL/OSL-DA-15 Risoe reader equipped with an ${ }^{90} \mathrm{Sr} /{ }^{90} \mathrm{Y}$ beta source (LSCE laboratory, Gif-sur-Yvette) or similar equipment (UQAM Laboratory, Montreal) to which was fitted a Single-Grain Laser System (Duller et al., 1999). For the measurements done in the LSCE laboratory, quartz grains were fixed on stainless steel discs with silicon oil using a point of $1 \mathrm{~mm}^{2}$ section; this technique allows the deposition of about 50 grains on each disc. The measurements performed with the Single-Grain Laser System were made with discs having a grid of $10 \times 10$ holes drilled into the surface. A total of 100 aliquots can therefore be measured with a single disc. Because of the diameter and depth of the holes (300 $\mu \mathrm{m})$, each aliquot is composed of less than 10 grains. Optical stimulation was done at LSCE with blue light emitting diodes (LEDs) with a peak emission at 470 $\mathrm{nm}$ (Bøtter-Jensen et al., 2000) and at UQAM with a $10 \mathrm{~mW} \mathrm{Nd}: \mathrm{YVO}_{4}$ diode-pumped laser (532 nm). OSL signals were detected with EMI 9235QA photomultiplier tubes through three $3 \mathrm{~mm}$ Hoya U-340 filters.

The Single-Aliquot Regenerative-dose protocol (SAR) (Murray and Wintle, 2000) was used to determine the ED value of each aliquot. This protocol allows the construction of a regenerative OSL doseresponse curve and correct for sensitivity changes which may affect the quartz. The ED of an aliquot was calculated by interpolation of the corrected natural OSL signal onto a saturating exponential curve fitted towards the corrected regenerative dose signals. A test was introduced at the end of the measurement cycle in order to control for the efficiency of the protocol. Moreover, during this test, the discs were exposed to infrared stimulation to check for the absence of feldspars in the aliquots; their contribution to the natural signal was estimated to be systematically lower than $1.5 \%$. Finally, recovery dose tests were undertaken for all samples in the LSCE laboratory: after aliquots had been bleached with the LEDs for $200 \mathrm{~s}$ and given a known radiation dose of the same order than the expected ED, the SAR protocol was applied to recover this artificial dose using the same pre-heat treatment $\left(220{ }^{\circ} \mathrm{C}\right.$ for $\left.10 \mathrm{~s}\right)$ than those used for ED determinations. Results indicated no systematic bias since the dose was recovered within $\pm 5 \%$, and proved for the appropriateness of the measurement conditions.

\subsection{Luminescence ages}

For each sample, between 200 and 400 small aliquots ( $<10$ grains) were measured at UQAM and between 24 and 48 at LSCE (large aliquots). Fig. 5 shows a plot in ranked order of both sets of EDs for 


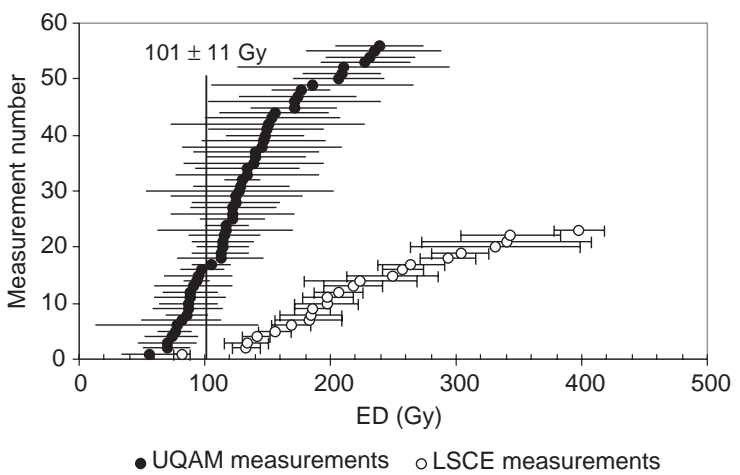

Fig. 5. Values of EDs for sample AP00-M2 given in ranked order, determined at UQAM-full circles-with small aliquots $(<10$ grains) or LSCE-open circles-with larger aliquots (about 50 grains).

sample AP00-M2 which is the most recent sample associated with the marine deposit identified in the upthrown fault block. Values measured at LSCE are all but one greater than $120 \mathrm{~Gy}$, whereas values as low as 55 Gy were measured at UQAM. Moreover, for this set, the values range from 55 to $240 \mathrm{~Gy}$. A combination of reasons may explain this difference. Firstly, all grains may have experienced different microdosimetry environments which cannot be taken into account for age estimation. However, a simple dosimetric calculation indicates that this effect, even if it is very likely, cannot explain such dispersion. Consequently, one must also hypothesize that all grains have not had their OSL signal resetted to zero during transport and deposition. Mean EDs were then calculated with the minimum age model (Galbraith et al., 1999) in order that the poorlybleached grains (or aliquots) would have as little impact as possible on the ED determinations. For sample AP00-M2, the mean ED is $101 \pm 11$ Gy (Fig. 5 ) and leads to an age of $72 \pm 10$ ky (Table 2) which corresponds to the beginning of OIS 4. However, with the same approach, had we only considered the individual ED values measured at LSCE which probably average the microdosimetric effects, a mean ED of about 150 Gy would have been obtained, resulting in an OIS 5 age (around 108 ky). This example illustrates the possibility that some ages might be slightly underestimated. The comparison of OSL data with geological informations is, therefore, essential.

\section{Geochronological interpretation of sediments in Asperillo cliffs}

\subsection{Morpho-sedimentary significance of paleoaltera- tions (Palaeosols Ps1 and Ps2)}

Weathering features, together with the evidence of an earlier pedogenic signal, clearly indicate a pause in the sedimentation at the top of the coastal plain deposits. As aforementioned, offshore seismic reflection surveys provide evidence of a progressive accumulation of offlapping Pleistocene sedimentary wedges onto the Gulf of Cadiz that enlarged the subaerial zone of the coastal plain subject to pedogenesis. In this scenario the repeated redoximorphic processes printed on the earlier red soil (Ps1), related to relevant oscillations of the phreatic level seem to represent the onset of new environmental conditions forced by the push of a rising sea level on the ancient coastal plain zone.

Processes of iron redistribution in palaeosol 2 (Ps2) were remarkably less intense than those of Ps1, as evidenced in micromorphology. This suggests a shorter sedimentary hiatus, which may be chronologically coeval to one or more 'palaeosols' of the fluvial or marine deposits of the upthrown block of the TLF.

\subsection{Upthrown fault block (Fig. 2, Table 1)}

\subsubsection{Palaeosol Ps1, fluvial and marine units, and aeolian deposits $U o$}

Mineralogical and micromorphological features of Palaeosol Ps1 suggest that it was generated under climatic conditions similar to interglacial or interstadial conditions. The development of this soil suggests a long hiatus in sedimentation after deposition of the underlying Pliocene-Pleistocene coastal plain and deltaic sediments. The occurrence of an argillic horizon affected by redox processes suggests that during the last stages of the evolution of the paleosol the water table was oscillating and close to surface. In our opinion this is consistent with the observed vertical evolution of the area that first was occupied by a tide-influenced fluvial coastal plain (fluvial unit) and, eventually, was transgressed by a shallow sea. As a whole this represents a rise of sea level that culminated with the beach deposits of the marine unit during the highstand. 
The transition from the marine to the aeolian unit Uo marks the subsequent fall or stillstand of sea level.

After an erosional phase and a hiatus in sedimentation of unknown duration (Table 1), there are still some $3 \mathrm{~m}$ of essentially non-weathered sands, very much like the topmost part of the aeolian U3 observed in the downthrown fault block.

Dating the rocks in the upthrown fault block was attempted using radiocarbon but samples collected from the silty organic layers of the fluvial unit yielded ages beyond the range of the radiocarbon method (Zazo et al., 1999a). The OSL method was applied to four samples from the fluvial and marine deposits which gave ages ranging from $102 \pm 17$ to $72 \pm 10 \mathrm{ky}$. Considering the remarks made about the possible underestimation of some OSL ages, it cannot be excluded that these sediments were deposited during two successive highstands of the sea level during OIS 5. Fluvial deposits in which tidal influence was identified (Zazo et al., 1999a) suggest a relative high sea level in the area during sedimentation. The overlying aeolian unit Uo was dated to $64 \pm 8 \mathrm{ky}$ and could then have been deposited during the late OIS 4 (Table 2).

According to published regional data, on marine units deposited during the Quaternary Interglacials (Zazo et al., 1994, 1999b; Yll et al., 2003), we assign the marine unit in El Asperillo to a highstand during the Last Interglacial (OIS 5).

It is still more difficult to obtain the age of paleosol Ps1. We tentatively suggest that the early red soil was developed under interglacial climate conditions (OIS 7 or the first part of OIS 5).

\subsection{Downthrown fault block (Fig. 2, Table 1)}

The genesis of paleosol Ps2 required climatic conditions similar to paleosol Ps1, although the weathering profile is less developed. We lack age indications, but estimates are based on the ages obtained for the overlying deposits. The mean OSL age of the aeolian deposits U1 is 106 $\pm 19 \mathrm{ky}$ (Table 2) and suggest a deposition during the late OIS 5 . Considering the weathering profile at the top of U1 and the supersurface separating it from U2, we suggest that Ps2 formed during the temperate Last Interglacial (OIS 5).
According to these considerations, Ps 2 could be coeval with the deposition of fluvial and marine units described in the upthrown fault block (Table 1).

\subsubsection{Aeolian unit U2}

This unit accumulated from OIS 4 to early OIS 2 (OSL ages ranging from $74 \pm 7$ to $32 \pm 3$ ky and radiocarbon ages ranging from $>45$ ky to $17,720 \pm$ $400 \mathrm{ky}$, Zazo et al., 1999a) under prevailing W/NW winds. Pollen and wood macro-remains reveal significant climate changes. During the first part of deposition of U2 (OIS 4), microthermic wood macro-remains indicate a relatively arid climate that became moister with time (OIS 3) as shown by the occurrence of a thermo-mediterranean vegetation layers rich in organic matter and the presence of incised paleovalleys.

\subsubsection{The supersurface separating aeolian units U2 and $U 3$}

The U2/3 supersurface is the most widespread erosional surface in the downthrown fault block and indicates a change to more arid conditions, as it truncates horizons burrowed by vegetation. ${ }^{14} \mathrm{C}$ ages of organic layers below (layer a, Fig. 2) and above (layer b, Fig. 2) the supersurface are $\sim 21 \mathrm{ky}$ cal BP and $\sim 16$ ky cal BP, respectively, meaning that it formed probably during the Last Glacial Maximum. OSL ages (samples AP00D2 and AP00D1) fit well in this range.

\subsubsection{Aeolian unit U3}

It is the richest in organic layers, deposited between $\sim 16 \mathrm{ky} \mathrm{cal} \mathrm{BP}$ and $\sim 12 \mathrm{ky}$ cal BP (Fig. 2), data supported by a pollen content indicative of the Last Deglaciation (Zazo et al., 1999a).

The younger-most organic layer interbedded with aeolian deposits, but close to the top of U3, is mudcracked, a feature that we interpret as indicating the transition to more arid conditions. Thus, we propose that U3 accumulated during the Last Deglaciation, and the organic-rich layers correspond to the BølingAllerød interstadial. The interstadial has been dated in drill samples from the southwestern Iberian Peninsula as 15-13 ky cal BP (Bard et al., 2000). The occurrence of mud cracks indicates probably an arid event that may be correlated with the Younger Dryas, centred in this area around 12 ky cal BP (Bard et al., 
2000). This implies that the uppermost aeolian deposits in U3 represent the earliest Holocene.

\subsubsection{The supersurface separating aeolian units U3 and U4 (SsFe, Table 1)}

Mineralogical data, such as the occurrence of goethite, suggest that the supersurface $\mathrm{SsFe}$ records a moist, temperate climate. The only pollen record available in the littoral area of southwestern Iberian Peninsula indicates that these conditions existed between $\sim 10 \mathrm{ky}$ cal BP and $\sim 6.5 \mathrm{ky}$ cal BP (Santos et al., 2003). This period (Holocene Climatic Optimum) is characterized by a rapid rise of sea level that ranged between 5.7 and $8 \mathrm{~mm} /$ year, as recorded in estuaries of southern Spain (Dabrio et al., 2000) and Portugal (Boski et al., 2001). The end of this period marks the maximum flooding surface and the Flandrian maximum (Zazo et al., 1994). After this, both the rates of sea level change (values around $2.6 \mathrm{~mm} /$ year) and sedimentation rates in estuaries decreased (Lario et al., 2002).

The end of the accumulation of the SsFe supersurface is marked by late Neolithic-Chalcolithic lithic workshops, dated in this area as $\sim 5.0 \mathrm{ky}$ cal BP (Martín de la Cruz et al., 2000). The artefacts rest on the $\mathrm{SsFe}$ supersurface and appear associated with the aeolian unit U4.

\subsubsection{Semimobile and mobile aeolian units (U4 to U7)}

Aeolian U4 coincides with the beginning of an arid trend ca. 5.0 ky cal BP, also recorded in lagoons of southwestern Portugal (Santos et al., 2003), and the first recorded stages of progradation of the emergent spit-bar in the Atlantic littoral of SW Iberian Peninsula (Zazo et al., 1994).

Aeolian U5: A new arid period at $\sim 2.7 \mathrm{ky}$ cal BP coincided with an increase of coastal progradation (Zazo et al., 1994; Dabrio et al., 2000) and accumulation of the oldest preserved foredunes in this littoral (Borja et al., 1999). These data agree with the ${ }^{14} \mathrm{C}$ age of 2,475 cal BP (Zazo et al., 1999a) from charcoal inside U5. However sedimentation continued during Roman and Medieval times, as indicated by archaeological remains associated to this aeolian unit.

Aeolian U6 includes high, well-developed transverse aeolian dunes that accumulated, at least, in part during the active life of the coastal watch towers (16th-17th centuries, Anon., 1756) moved by winds from the SW.

The youngermost aeolian U7 is only observed in some places. Dunes began to accumulate after the 17 th century and they are still active under winds from the SW.

\section{The Abalario Dome: upwarping and deformational processes}

The El Asperillo cliff (Fig. 1) constitutes the truncated SW littoral flank of the so-called Abalario Dome, an elliptical-shaped topographic feature, elongated in a NW-SE direction (Fig. 6). This elevated area served as anchor to the Holocene spit-bars and dune systems forming the Doñana littoral bar (Fig. 1) that eventually closed the Guadalquivir river basin (Zazo et al., 1994; Rodríguez Ramírez et al., 1996).

Numerical data extracted from the 1:200,000 DEM of Spain (SGE, 1997) show a mean length of the dome of ca. 48-51 km for the NW-SE major axis and $12.5-16 \mathrm{~km}$ for the NE-SW minor axis. The mean altitude of the dome along the present watershed is $70-75 \mathrm{~m}$ asl, but its real ridge-line is located near the sea-cliff where active dunes reach a maximum altitude of $106 \mathrm{~m}$ (El Asperillo geodetic bench-mark). The drainage pattern within the dome is pseudo-radial and divergent, forced by the elliptical shape of the topography. However, watercourses do not reach the top of the dome, and the zone between the watershed and the dome ridge-line lacks a defined drainage. This zone contains several shallow ponds distributed at random (Fig. 6). Strikingly enough, the drainage pattern is asymmetric, with the longer streams on the inland (NE) flank flowing to La Rocina rivervalley. In contrast, drainage lines in the coastal (SW) flank are mainly constituted by short gullies that dissect the present sea-cliff. However gully systems at the SE perimeter of the dome, near Matalascañas, are presently buried under recent aeolian dunes.

In detail, the drainage pattern along the inland flank (NE) is sub-parallel and very similar to the dissection patterns observed in periclinal terminations and diapirs. A few remarkable features in this area deserve closer examination. One of these is the occurrence of unusual ephemeral ponded zones at the headwaters of the streams (Fig. 6). The ponded 


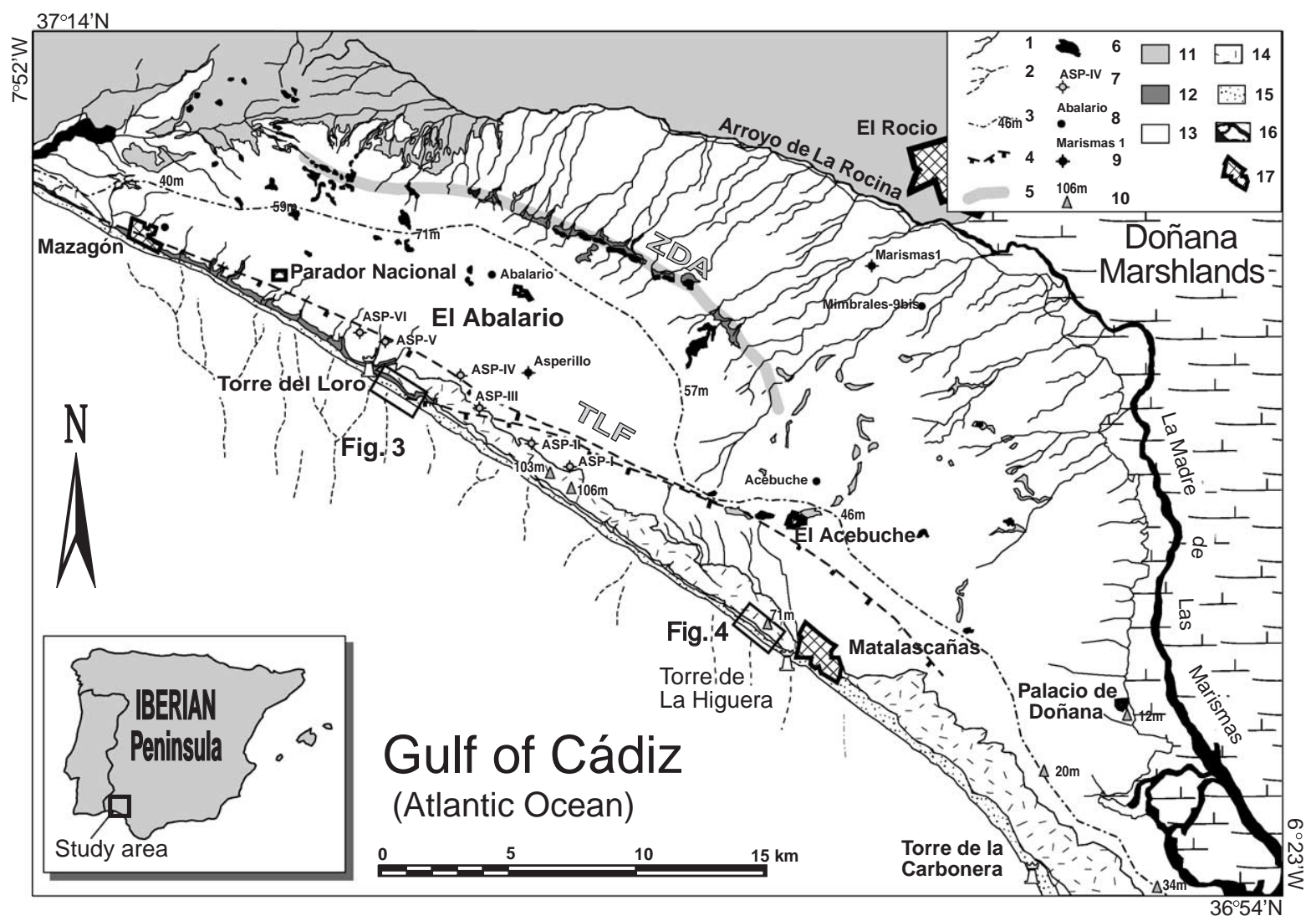

Fig. 6. Geological and Geomorphological synthetic map of the El Abalario Dome. Legend: (1) Subaerial drainage network; (2) offshore drainage lines; (3) Drainage divide with height spots; (4) Torre del Loro (TLF) fault lines; (5) Zone of drainage anomalies at the dome top; (6) shallow ponds and ponded areas (7) Lignite exploration wells (IGME, 1980); (8) Hydrogeological exploration wells (Salvany and Custodio, 1995); (9) Petroleum exploration wells (ITGE, 1990); (10) Geodetic bench-marks: 106 m bench-mark corresponds to El Asperillo; (11) Pliocene-Pleistocene sandy coastal-plain deposits; (12) Late Pleistocene upthrown block deposits; (13) Late Pleistocene downthrown block deposits and Holocene dune systems; (14) coastal active dune systems on sea-cliff; (15) Present beach deposits; (16) Marshlands (in black: channel systems); (17) Localities.

zones are randomly distributed in the NW and SE sectors of the dome. In contrast, ponds in the northern flank follow a line oriented NW-SE, roughly at right angle to the 'sub-parallel' drainage lines, forming the so-called Ribetehilos-Peladillo palustrine system. Such a lineation, or zone of drainage anomalies (ZDA), can be interpreted as a small-scale replica of those described by Ollier (1981), Marple and Talwani (1993) and Summerfield (1995) in larger-scale areas affected by active upwarping (of tectonic, isostatic or flexural origin). Other drainage anomalies within the ZDA include channel diversions and deflections along the uppermost segments of the streams also following NW-SE trends (Fig. 6).
The ZDA is also linked to the linear outcrop of the ancient Pliocene-Pleistocene coastal plain-deltaic materials, which constitute the oldest rocks exposed within the dome. The concurrence of ponded zones and other drainage anomalies with the abovementioned anomalous geological lineation strongly suggests that the main mechanism controlling the surface hydrology in the El Abalario Dome is faulting (or gravitational sliding) linked to active upwarping. Some hydrological features within the ZDA and its hypothetical westward prolongation into the Doñana marshlands (vertical flows of groundwater, upward head gradients, and deep flowing wells; Manzano et al., 2001) suggest that faulting generates a selective 
lineal path for the escape of overpressured fluids from the subjacent Plio-Pleistocene deltaic unit towards the ground surface.

\subsection{Evidences of recent faulting in the "El Abalario Dome"}

It is commonly accepted that orthogonal fault systems (NW-SE and E-W) outlining individual blocks control both the occurrence of swamped and elevated areas along the Huelva littoral (Flores and Rodríguez Vidal, 1994) and the very variable depth at which the top of the deltaic unit is found by boreholes in this area (Viguier, 1977; Goy et al., 1994; Salvany and Custodio, 1995; Zazo et al., 1999a). This is the case of suspected faults such as Tinto, Torre del Loro, Bajo Guadalquivir and Guadiamar-Matalascañas. The Torre del Loro Fault (TLF; Fig. 6) is the only one directly affecting the Abalario Dome. The TLF has been previously considered as an E-W trending normal fault inferred from the outstanding anomalies of the Late Pleistocene stratigraphy along the El Asperillo cliff (Goy et al., 1994; Zazo et al., 1999a).

Zazo et al. (1999a) estimated the minimum fault throw on the TLF as $18-20 \mathrm{~m}$ for the Late Pleistocene, but borehole data from lignite and hydrogeology explorations carried out by IGME (1980) and Salvany and Custodio (1995) indicate a minimum accumulated offset of ca. $45 \mathrm{~m}$ since at least the Early Pleistocene. This is deduced from the displacement of the top of the 'Plio-Pleistocene deltaic unit' described by Salvany and Custodio (1995) from $20 \mathrm{~m}$ bsl (well ASPVI, Fig. 6) in the upthrown block to $65 \mathrm{~m}$ bsl in the downthrown block (wells ASP-III, Fig. 6) in a distance of $3.7 \mathrm{~km}$.

Correlation of borehole data suggests that the fault zone is dip-slip stepped with, at least, two fault lines oriented roughly parallel to the present coastline (WNW-ESE). Such tectonic structures fit to a model of high-angle gravity faults dipping towards the sea, and trends adapted to the elliptical geometry of the dome, better than the previously proposed E-W trending. The new fault geometry proposed in this paper, is further supported by the absence of E-W faults in reflection seismic profiles (IGME, 1990).

In addition, the wedge shaped geometry delineated by the large-scale bounding surfaces (dips 5$15^{\circ} \mathrm{NNW}$ ) within the aeolian units (U2 and U3) adjacent to the TLF (Fig. 2), provides evidence that the downthrown block was tilted to the W-NW forming a gentle progressive unconformity. All these features indicate synsedimentary deformation and additional data suggest the development of a faultsag over the TLF hanging wall. The fault-sag is evidenced by the occurrence of hectometre-wide (palaeo) valleys parallel to the fault, as well as small slumps observed in dune foresets within the first 2.5 $3.5 \mathrm{~km}$ away from the fault wall. Whatever the case, a non-tectonic large-scale gravitational sliding along the TLF can also explain the described set of features.

The OSL ages of the oldest materials in the downthrown block (aeolian unit U1) (Table 2) strongly suggest that an initial ground failure producing the TLF fault plane took place before OIS 4, maybe at the end of the OIS 5. Unfortunately, OSL dates of the upthrown block of the fault (Table 2) do not allow a more accurate age assessment. Moreover, as said before, the activity of the TLF could have continued (in an irregular way) until the eventual burying of the fault scarp after the deposition of the aeolian unit U3, ca. $10 \mathrm{ky}$ cal BP (Table 2). Eventually, the iron crust-like supersurface ( $\mathrm{SsFe}$ ) sealed the fault trace and was, in its turn, covered by Holocene aeolian unit. In short, the TLF can be linked to a mega-landslide event that generated a fault-scarp shoreline longer than $17 \mathrm{~km}$ (Fig. 6) probably during OIS 5, which was completely buried by early Holocene sediments, before $5 \mathrm{ky}$ cal BP.

According to the diachronism of the materials exposed at the two fault blocks, there are remarkable differences in geomorphologic features (Figs. 3A and 4A). In the upthrown fault block there are plenty of small-size landslides and hanging valleys. The multicreek hierarchical drainage begins in the interior dome, dissects the present sea-cliff, and continues as offshore channels (Fig. 6). In contrast, the trace of the sea-cliff in the downthrown fault block is almost rectilinear, with erosion restricted to active gullying in minor creeks and rills, unconnected to the drainage system of the dome. These differences highlight the long erosional history of the upthrown fault block as compared with the much younger (undissected) landscape of the downthrown fault block.

The pre-faulting history of the Abalario Dome is preserved in the upthrown block, where Zazo et al. 
(1999a) found evidence of episodic instability linked to the development of widespread dewatering horizons within the shallow-marine deposits of the Marine unit. However, soft-sediment deformations also occur immediately beneath and above the complex basal palaeosol (Ps1) adjacent to the TLF (Fig. 3C, D). Deformation beneath palaeosol Ps1 consists of classical convex-upwards lamination and dewatering structures (micro-dish and pillow structures) in the deeply weathered sandy materials, indicating intense dewatering. The indurated surfaces of the dewatered sandy levels are dome shaped (2.5-3 m long, 1-1.5 m wide) with major elongation orientated parallel to the present coastline (ca. N120-130 $\mathrm{E}$ ). The internal topography of surfaces is hummocky, and is affected by horizontal burrowing and pit-like concentric structures (Fig. 3C, D). Above the palaeosol (Ps1), flat-based, mound-shaped layers occur. These are made up of a disorganised mass of iron-concretions and armoured sand balls in a muddy-sandy matrix. Hummocky-shaped iron crusts similar to those found in the basal dewatered sandy domes also coat the surface of the mound-shaped layers.

Similar sets of features have been described associated to subaerial mud volcanism of recent deltaic environments within convergent plate boundaries (Aslan et al., 2001). This assumption will imply the occurrence of subaerial mud-volcanism prior and during OIS 5 in the studied zone. Mud diapirism, volcanism, gas seepage, and fluid-escape structures are common in the offshore Gulf of Cadiz affecting the Pleistocene and even Holocene units (Baraza and Ercilla, 1996; Fernández Puga et al., 2000, 2002; Somoza et al., 1999, 2000; Llave et al., 2001), usually related to overpressure caused by the SW headwards gravitational sliding of the Betic Olitostrome Front (Fig. 1), which can be considered as a preliminary candidate to explain upwarping in the studied zone.

In this scenario, large-scale gravitational sliding promoted by upwarping can explain the origin of the TLF within the framework of the overall process of upwarping of the 'El Abalario Dome'. Uplift in the upthrown TLF block is confirmed by the present topographic elevation (12 m asl, Fig. 2) of the Late Pleistocene shallow marine deposits, assumed to belong to the OIS 5. Supposing a sea-level position close to the present one during a sea-level highstand of this interglacial with averaged age $100 \mathrm{ky}$, a $12 \mathrm{~m}$ value is the maximum 'uplift' of the Abalario Dome and the minimum 'throw' of the TLF, deducible from the available data.

Whatever the case, the ultimate mechanism for uplift and upwarping within the Abalario Dome is not clear. Transpressive tectonics linked to the NNW-SSE collision of the African and Eurasian Plates (Ribeiro et al., 1996) cannot be totally rejected as the initial origin of the Abalario Dome. Positive flower structures plunging to the North have been described within the Portuguese offshore zone of the Gulf of Cadiz (Maestro et al., 1998). Many of these structures are deep-seated in flexures of the Betic basement in the foreland margin of the Guadalquivir Basin, but the deformation is transmitted upwards reaching the Late Pleistocene deposits (Llave et al., 2001).

\section{Conclusions}

The sedimentary record of El Abalario area includes the most recent part of the sedimentary fill of the western Guadalquivir basin. It records the interaction of sedimentation on a coastal plain (including changes of sea level of varying magnitudes) and upwarping probably related to escape of over-pressurized fluids (dewatering, mud volcanism) that eventually produced gravitational faults roughly parallel to the present coastline (TLF, Fig. 6) in the southwestern flank of the upwarped El Abalario dome.

The oldest exposed materials is a palaeosol (Ps1) developed on a prograding coastal plain of PliocenePleistocene age, probably prior to the Last Interglacial (Fig. 7A). The palaeosol represents a hiatus in sedimentation under a temperate, moist climate with a dry season as reflected by the micropedological features. Later, the oscillating water table favoured redox processes and mottling. Then, a combination of rising sea level and fluid escape from underlying lithosomes promoted dewatering and subaerial mud volcanism.

Renewed sedimentation in a coastal braid plain with tidal influence (Figs. 7B and 8 phase 1) during the OIS 5 (OSL ages) laid down fluvial deposits. To the SE, in areas away from the coast and presumably more elevated topographically, palaeosol Ps2 may 


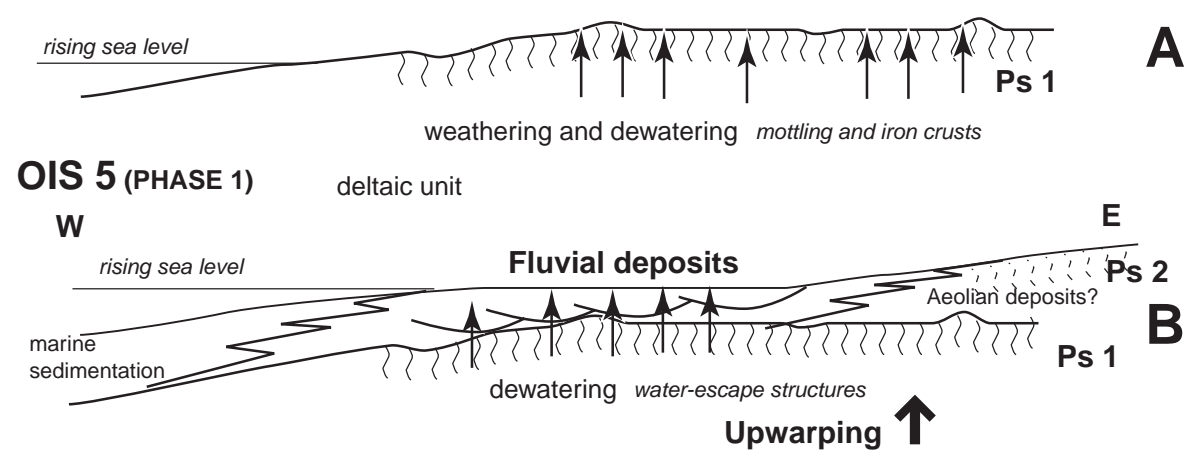

\section{OIS 5 (PHASE 2) NW}
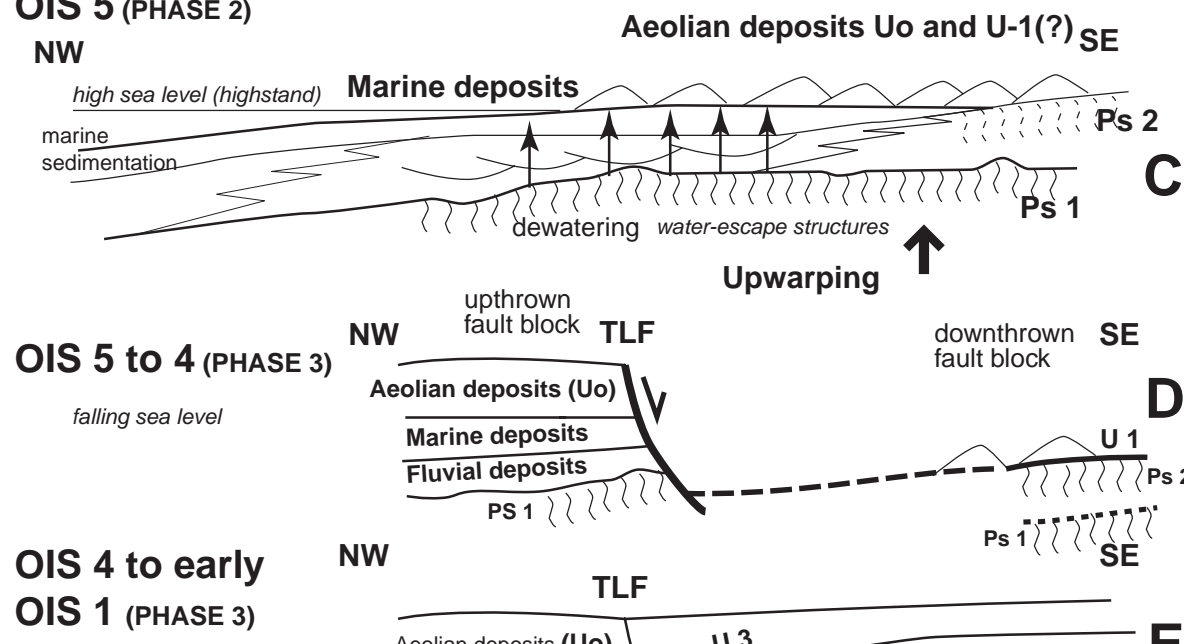

sea level subjected to large and small changes
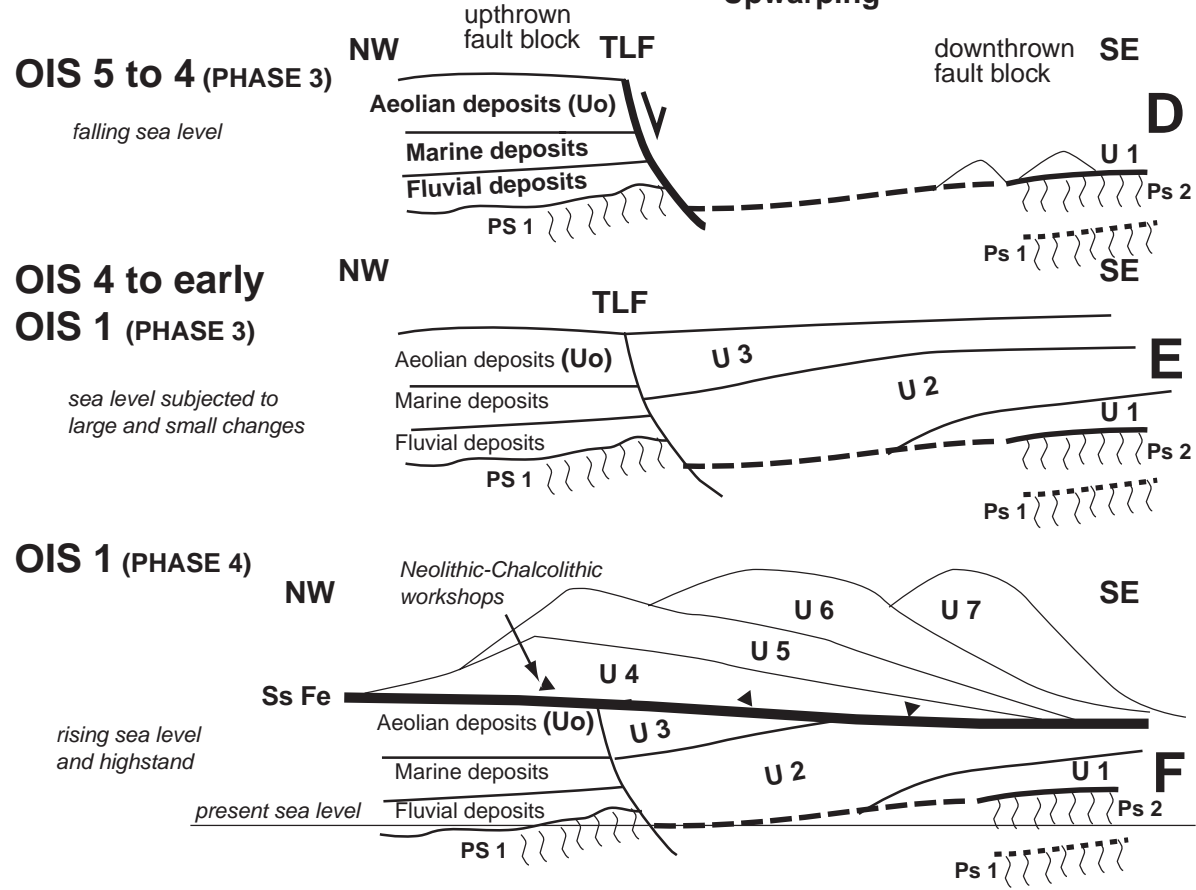

Fig. 7. Selected sections to explain key steps in the evolution of the El Abalario Dome during the last two glacial cycles and the stratigraphic architecture of units exposed along the El Asperillo cliff (see locations in Fig. 8).

have been forming at this time under a temperate, moist climate with a dry season, and less intense redox processes than in Ps1.
A rise of sea level led the progressive inundation (flooding) of the former coastal plain allowing the installation of shallow marine and aeolian environ- 

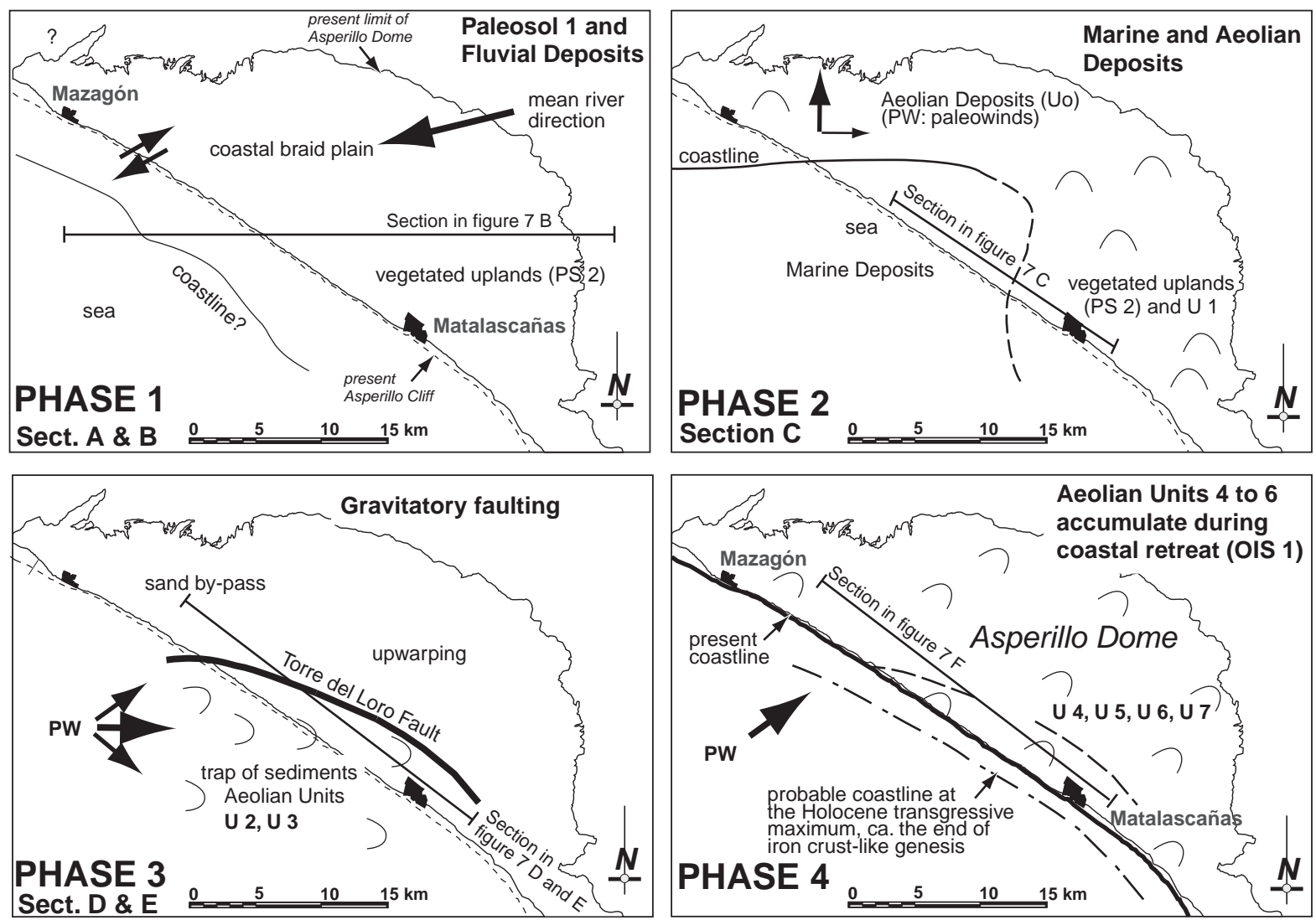

Fig. 8. Palaeogeographical sketch maps of the El Abalario Dome area showing key steps in the evolution during the Late Pleistocene and Holocene.

ments during OIS 5 (c or a) (Figs. 7C and 8 phase 2). Prevailing winds blew from the south.

Gravitational sliding along the (future) TLF, between OIS 5 and OIS 4, promoted an upthrown block to the NNE and a downthrown block to the SSE, generating a first faulted sea-cliff (Figs. 7D and 8 phase 3 ).

The downthrown block served as nucleus for aeolian sedimentation (aeolian units U1, U2, and U3) in the area which accumulated against the fault scarp (Figs. 7E and 8 phase 3). The first aeolian unit (U1) accumulated during OIS 5 and terminates upwards in a supersurface associated to a thick weathering profile indicative of moister conditions.

The thicker and more continuous laterally, aeolian unit 2 (U2) accumulated from OIS 4 to early OIS 2 under prevailing W/NW winds. Pollen and wood macro-remains evidence significant climate changes from conditions relatively arid (OIS 4) to moist during OIS 3.

Sedimentation of aeolian unit 3 (U3) began during the Last Deglaciation (16-12 ky cal BP, radiocarbon and OSL ages). Climate evolved towards arid conditions that caused mud-cracking of organic layers, dated as 13,870-11,950 ky cal BP, probably representing the Younger Dryas in the area.

The supersurface that fossilizes the TLF and its associated iron crust-like SsFe layer observed all along the Asperillo sea cliff (Fig. 7) developed in OIS 1, during the Holocene Climatic Optimum, under a moist and temperate climate (9 ky cal BP-6.5 ky cal BP).

The general trend to aridity began ca. $5 \mathrm{ky}$ cal BP evidenced by the onset of the accumulation of large mobile and semimobile dune systems (U4 to U7). A remarkably arid event occurred at ca. $2.7 \mathrm{ky}$ cal BP marked by the beginning of accumulation of aeolian 
U5 and progradation of the emergent spit bars at estuary mouths.

Renewed investigation in the El Abalario dome area suggests that many of the previously suspected EW trending faults, including the TLF fault, run actually subparallel to the coastline (NW-SE) closely linked to the dome-flank geometry, and have a presumably nontectonic origin. The TLF can be considered as a megalandslide that initially collapsed the coast (SSW) during the OIS 5-OIS 4, triggered by the continuous upwarping of the El Abalario Dome. The occurrence of sliding of the Betic Olistostrome towards the SW and transpressive tectonics, together with overpressure (fluid escape) and diapiric processes in this zone of the Gulf of Cadiz makes it difficult to unravel a single mechanism of upwarping. In addition, the presented data suggest that fluid overpressure within the Pliocene-Pleistocene sedimentary wedge of coastal plain deposits (Deltaic unit) might also play a relevant role in upwarping.

\section{Acknowledgements}

Authors are thankful to Prof. E. Custodio for his kind review of the hydrological aspects of the paper, Paola Carracedo for OSL sample preparation, Prof. M. Lamothe (UQAM, Montreal) who made available the Single-Grain Laser System, S. Huot for his assistance in the EDs calculation with the minimum age model, Prof. A.M. Harvey and Dr. A.J. Plater for their constructive suggestions and corrections. Financial support from Spanish Projects BTE2002-1065 and BTE20021691. This is a contribution to IGCP 495 and to the INQUA “Coastal and Marine Processes Commission".

\section{References}

Adamiec, G., Aitken, M., 1998. Dose-rate conversion factors: update. Ancient TL 16 (2), 37-50.

Aitken, M.J., 1998. An introduction to optical dating. Oxford University Press.

Anon., 1756. Relación de las plazas, torres, puestos fortificados, edificios militares y poblaciones de la costa de Andalucia. Desde la raya occidental del reino de Granada hasta la de Portugal en Ayamonte. Según el estado en que se hallan en el año 1756. Manuscrito Militar de Cadiz, pp. 49-54.

Aslan, A., Warne, A.G., White, W.A., Guevara, E.H., Smyth, R.C., Raney, J.A., Gibeaut, J.C., 2001. Mud volcanoes of the Orinoco Delta, Eastern Venezuela. Geomorphology 41, $323-336$.

Bard, E., Rostek, F., Turon, J.L., Gendreau, S., 2000. Hydrological impact of Heinrich events in the subtropical northeast Atlantic. Science 289, 1321-1324.

Baraza, J., Ercilla, G., 1996. Gas-charged sediments and large pockmark-like features on the Gulf of Cádiz slope (SW Spain). Marine and Petroleum Geology 13, 253-261.

Barrón, V., Torrent, J., 1987. Origin of red-yellow mottling in a ferric acrisol of southern Spain. Zeitschrift für Pflanzenernährung und Bodenkunde 150, 308-313.

Borja, F., Díaz del Olmo, F., 1994. El acantilado de El Asperillo: Cuaternario reciente y fases históricas en el litoral de Huelva. Geogaceta 15, 101-104.

Borja, F., Díaz del Olmo, F., 1996. Manto eólico litoral (MEL) del Abalario (Huelva, España): Episodios morfogenéticos posteriores al 22.000 BP. In: Pérez Alberdi, A., Martini, A.P., Chesworth, W., Martínez Cortizas, A. (Eds.), Dinámica y Evolución de Medios Cuaternarios, Xunta de Galicia, Santiago de Compostela, Spain, pp. 375-390.

Borja, F., Zazo, C., Dabrio, C.J., Diaz del Olmo, F., Goy, J.L., Lario, J., 1999. Holocene aeolian phases and human settlements along the Atlantic coast of southern Spain. Holocene 9, $333-339$.

Boski, T., Moura, D., Veiga-Pires, C., Camacho, S., Duarte, D., Scott, D.B., Fernández, S.G., 2001. Postglacial sea-level rise and sedimentary response in the Guadiana Estuary, Portugal/ Spain border. Sedimentary Geology 150, 103-121.

Bøtter-Jensen, L., Bulur, E., Duller, G.A.T., Murray, A.S., 2000. Advances in luminescence instrument systems. Radiation Measurements 32, 523-528.

Bullock, P., Federoff, N., Jongerius, A., Stoops, G., Tursina, T., 1985. Handbook for soil thin section description. Waine Research Publications, United Kingdom.

Caratini, C., Viguier, C., 1973. Etude palynologique et sédimentologique des sables holocènes de la falaise littoral d'El Asperillo (province de Huelva). Estudios Geológicos 29, $325-328$.

Dabrio, C.J., Borja, F., Zazo, C., Boersma, R.J., Lario, J., Goy, J.L., Polo, M.D., 1996. Dunas eólicas y facies asociadas pleistocenas y holocenas en el acantilado del Asperillo (Huelva). Geogaceta 20, 1089-1092.

Dabrio, C.J., Zazo, C., Goy, J.L., Sierro, J., Borja, F., Lario, J., Gonzalez, J.A., Flores, J.A., 2000. Depositional history of estuarine infill during the last postglacial transgression (Gula of Cadiz, Southern Spain). Marine Geology 162, 381-404.

Duller, G.A.T., Bøtter-Jensen, L., Kohsiek, P., Murray, A.S., 1999. A high-sensitivity optically stimulated luminescence scanning system for measurement of single sand-sized grains. Radiation Protection Dosimetry 84, 325-330.

Fernández Puga, M.C., Somoza, L., Pinheiro, L.M., Vázquez, J.T., Lowrie, A., León, R., Díaz del Río, V., 2000. Tectónica salina y escapes de fluidos en el Golfo de Cádiz. Geotemas 1, 139-142.

Fernández Puga, M.C., Somoza, L., Maestro, A., Vázquez, J.T., Díaz del Río, V., Ivanov, M., 2002. The Guadalquivir Diapiric Ridge: deep tectonic and related gas surface structures. GBH coupling processes, fluid escape structures and tectonics at 
continental margins and ocean ridges TTR 11 Post-Cruise Meeting and International Conference Programme-Abstracts, Aveiro, (Portugal).

Fey, M.V., 1983. Hipótesis for the pedogenic yellowing of red soil materials. Technical communication-Republic of South Africa. Department of Agriculture and Fisheries 18, 130-136.

Flores, E., Rodríguez Vidal, J., 1994. Rasgos morfotectónicos del interfluvio costero Guadiana-Guadalquivir (Golfo de Cádiz). In: Arnáez, J., García Ruiz, J.M., Gómez Villar, A. (Eds.), Geomorfología en España. Sociedad Española de Geomorfología, Logroño, pp. 13-19.

Font Tullot, I., 1983. Climatología de España y Portugal. Instituto Nacional de Meteorología.

Galbraith, R.F., Roberts, R.G., Laslett, G.M., Yoshida, H., Olley, J.M., 1999. Optical dating of single and multiple grains of quartz from Jinmium rock shelter, northern Australia: Part I, experimental design and statistical models. Archaeometry 41, $339-364$.

Goy, J.L., Zazo, C., Dabrio, C.J., Lario, J., 1994. Fault-controlled shifting shorelines in the Gulf of Cadiz since $20 \mathrm{KyBP}$. Abstracts Volume 1st Symposium Atlantic Iberian Continental Margin, Lisboa.

Havholm, K.G., Kocurek, G., 1994. Factors controlling aeolian sequence stratigraphy: clues from super bounding surface features in the Middle Jurassic Page Sandstone. Sedimentology 41, 913-934.

Hernández Molina, F.J., Somoza, L., Lobo, F., 2000. Seismic stratigraphy of the Gulf of Cádiz continental shelf: a model for Late Quaternary very-high resolution sequence stratigraphy and response to sea-level fall. In: Hunt, D., Gawthorpe, R.L. (Eds.), Sedimentary Responses to Forced Regressions, Geol. Soc. London, Spec. Pub., vol. 172, pp. 329-362.

Hernández Molina, F.J., Somoza, L., Vázquez, J.T., Lobo, F., Fernández-Puga, M.C., Llave, E., Díaz del Río, V., 2002. Quaternary stratigraphic stacking patterns on the continental shelves of the southern Iberian Peninsula: their relationships with global climate and palaeoceanographic changes. Quaternary International $92,5-23$.

IGME 1980. Prospección General de Lignitos en el área de Mazagón (Huelva). ENADIMSA (ADARO). Plan Nacional de Energía IGME. 1-25 (unpublished report).

ITGE, 1990. Documentos sobre la geología del subsuelo de España. Tomo 1: Introducción, Guadalquivir-Golfo de Cádiz.

Kocurek, G., Havholm, K.G., 1993. Eolian sequence stgratigraphy—a conceptual framework. In: Weimer, P., Posamentier, H.W. (Eds.), Recent Advances in and Application of Siliciclastic Sequence Stratigraphy, American Association of Petroleum Geologists Memoir, vol. 58, pp. 393-409.

Lario, J., Zazo, C., Goy, J.L., Dabrio, C.J., Borja, F., Silva, P.G., Sierro, F., Gonzalez, F., Soler, V., Yll, R., 2002. Changes in sedimentation trends in SW Iberia Holocene estuaries. Quaternary International 93-94, 171-176.

Ledesma, S., 2001. Astrobiocronologia y estratigrafía de alta resolución en el Neógeno de la Cuenca del Guadalquivir-Golfo de Cádiz. PhD thesis, University of Salamanca, unpublished.

Llave, E., Hernández-Molina, F.J., Somoza, L., Díaz del Río, V., Stow, D.A.V., Maestro, A., Alveirinho Dias, J.M., 2001.
Seismic stacking pattern of the Faro-Albufeira contourite system (Gulf of Cádiz): a Quaternary record of paleoceanographic and tectonic influences. Marine Geophysical Research 22, 487-501.

Maestro, A., Somoza, L., Díaz del Río, V., Vázquez, J.T., MartínAlfageme, S., Alveirinho Dias, J.M., Barnolas, A., Vegas, R., 1998. Neotectónica transpresiva en la plataforma continental Suribérica Atlántica. Geogaceta 24, $203-206$.

Manzano, M., Custodio, E., Loosli, H., Cabrera, M.C., Riera, X., Custodio, J., 2001. Paleowater in coastal aquifers of Spain. In: Edmunds, W.N., Milne, C.J. (Eds.), Paleowaters in Coastal Europe: Evolution of Groundwater since the Late Pleistocene, Geological Society of London, Spec. Publ., vol. 189, pp. $107-138$.

Marple, R.T., Talwani, P., 1993. Evidence of possible tectonic upwarping along the south Carolina coastal plain from an examination of river morphology and elevation data. Geology $21,651-654$.

Martín de la Cruz, J.C., Delgado, M.R., Sanz, M.P., Vera, J.C., 2000. Novedades en el conocimiento sobre el Neolítico y Calcolítico en Andalucía: panorámica de una década de investigaciones. Trabalhos de Arqueología 16, 215-241.

Mayoral, E., Pendón, J.G., 1986-1987. Ictiofacies y sedimentación en las zonas costeras. Plioceno superior (?), litoral de Huelva. Acta Geológica Hispanica 21-22, 107-111.

Murray, A.S., Wintle, A.G., 2000. Luminescence dating of quartz using an improved single-aliquot regenerative-dose protocol. Radiation Measurements 32, 57-73.

Munsell Color, 1990. Munsell soil color charts. Macbeth Division of Kollmorgen instruments corporation, Baltimore, MD.

Ollier, C.D., 1981. Tectonics and landforms. Longman Scientifc and Technical, London.

Pastor, F., Leyva, F., Zazo, C., 1976. Mapa y Memoria explicativa de la Hoja 1042,El Abalario. Mapa Geológico de España e:1:50.000 ( $2^{\mathrm{a}}$ serie). IGME, Publicaciones del Ministerio de Industria, Madrid, $35 \mathrm{pp}$.

Riaza, C., Martínez del Olmo, W., 1996. Depositional model of the Guadalquivir-Gulf of Cádiz Tertiary Basin. In: Friend, P.F., Dabrio, C.J. (Eds.), Tertiary Basins of Spain: the Stratigraphic Record of Crustal Kinematics. Cambridge Univ. Press, Cambridge, pp. 330-338.

Ribeiro, A.J., Cabral, J., Baptista, R., Matías, L., 1996. Stress pattern in Portugal mainland and the adjacent Atlantic region, West Iberia. Tectonics 15, 641-659.

Rivas Martínez, S., 1987. Memoria del mapa de las series de vegetación de España escala 1:400.000. Publicaciones del Instituto de Conservación de la Naturaleza (ICONA), Madrid.

Rodero, J., Pallarés, L., Maldonado, A., 1999. Late Quaternary seismic facies of the Gulf of Cádiz, Spanish margin: depositional processes influenced by sea-level change and tectonic controls. Marine Geology 155, 131-156.

Rodríguez Ramírez, A., Rodríguez-Vidal, J., Cáceres, L., Clemente, L., Belluomini, G., Manfra, L., Improta, S., De Andrés, J.R., 1996. Recent coastal evolution of the Doñana National Park (SW Spain). Quaternary Science Reviews 15, 803-809.

Salvany, J.M., Custodio, E., 1995. Características litológicas de los depósitos pliocuaternarios del Bajo Guadalquivir en el área de 
Doñana: implicaciones hidrogeológicas. Revista Sociedad Geológica de España 8, 21-31.

Santos, L., Sánchez Goñi, M.F., Freitas, M.C., Andrade, C., 2003. Climatic and environmental changes in the Santo Andre Coastal area (SW Portugal) during the last 15000 years. In: Ruiz-Zapata, M.B., Dorado, M., Valdeolmillos, A., Gil, M.J. (Eds.), Quaternary Climatic Changes and Environmental Crises in the Mediterranean Region. Publ. Universidad Alcalá de Henares, Madrid, Spain, pp. 175-179.

SGE (Servicio Geográfico del Ejército), 1997. Mapa Digital de España, E: 1:200.000. Publ. Servicio Geográfico del Ejército, Madrid.

Schwertmann, U., Taylor, R., 1989. Iron oxides. In: Dixon, J.B., Weed, S.B. (Eds.), Minerals in Soils Environments, SSSA Book Series, vol. 1, pp. 379-439.

Somoza, L., Hernández Molina, F.J., De Andrés, J.R., Rey, J., 1997. Continental shelf architecture and sea-level cycles: Late Quaternary High-resolution stratigraphy of the Gulf of Cádiz, Spain. Geomarine Letters 17, 133-139.

Somoza, L., Maestro, A., Lowrie, A., 1999. Allochthonous blocks as hydrocarbon traps in the Gulf of Cádiz. Offshore Technology Conference Houston, Texas, USA, pp. 571-577.

Somoza, L., Díaz del Río, V., Hernández-Molina, F.J., León, R., Lobato, A., Alveirinho Dias, J.M., Rodero, J., TASYO Team, 2000. New discovery of a mud-volcano field related to gas venting in the Gulf of Cádiz: imagery of multibeam data and ultra-high resolution seismic. $3^{\text {er }}$ Symposium on the Iberian Atlantic Continental Margin, Cádiz, Spain, pp. 81-82.

Summerfield, M.A., 1995. Global Geomorphology. Introduction to the Study of Landforms. Longman Scientifc and Technical, London.

Viguier, C., 1977. Les grands traits de la tectonique de Basin neógène du Bas Guadalquivir. Boletín Geológico Minero 88, $39-44$.
Wintle, A.G., Murray, A.S., 1997. The relationship between quartz thermoluminescence, photo-transferred thermoluminescence and optically stimulated luminescence. Radiation Measurements 27, 611-624.

Yll, R., Zazo, C., Goy, J.L., Pérez-Obiol, R., Pantaleón-Cano, J., Civis, J., Dabrio, C.J., González, A., Borja, F., Soler, V., Lario, J., Luque, L., Sierro, F., González-Hernández, F.M., Lézine, A.M., Dénefle, M., Roure, J.M., 2003. Quaternary palaeoenvironmental changes in South Spain. In: Ruiz-Zapata, M.B., Dorado, M., Valdeolmillos, A., Gil, M.J. (Eds.), Quaternary Climatic Changes and Environmental Crises in the Mediterranean Region. Publicaciones Universidad Alcalá de Henares, Madrid, Spain, pp. 201-214.

Zazo, C., Dabrio, C.J., Goy, J.L., Menanteau, L., 1981. Parada 'Torre del Loro'-Guías de excursiones 'Estero de Domingo Rubio. Torre del Loro, El Aculadero. Faro de Chipiona' Actas $V^{a}$ Reunión Grupo Español de Trabajo del Cuaternario, Sevilla. $357-361$.

Zazo, C., Goy, J.L., Somoza, L., Dabrio, C.J., Belloumini, G., Improta, S., Lario, J., Bardají, T., Silva, P.G., 1994. Holocene sequence of sea-level fluctuations in relation to climatic trends in the Atlantic-Mediterranean linkage coast. Journal of Coastal Research 10, 933-945.

Zazo, C., Dabrio, C.J., Borja, J., Goy, J.L., Lézine, A.M., Lario, J., Polo, M.D., Hoyos, M., Boersma, J.R., 1999a. Pleistocene and Holocene aeolian facies along the Huelva coast (southern Spain): climatic and neotectonic implications. Geologie en Mijnbouw 77, 209-224.

Zazo, C., Silva, P.G., Goy, J.L., Hillaire-Marcel, C., Ghaleb, B., Lario, J., Bardaji, T., González, A., 1999b. Coastal uplift in continental collision plate boundaries: data from the Last Interglacial marine terraces of the Gibraltar Strait Area (South Spain). Tectonophysics 301, 95-109. 